\title{
Role of Immune Cell Diversity and Heterogeneity in Corneal Graft Survival: A Systematic Review and Meta-Analysis
}

\author{
Jun Zhu ${ }^{1,2}$, Takenori Inomata ${ }^{1,3,4,5,6, *}$, Antonio Di Zazzo ${ }^{7} \oplus$, Koji Kitazawa ${ }^{8,9} \oplus$, Yuichi Okumura ${ }^{1,3,5}$,

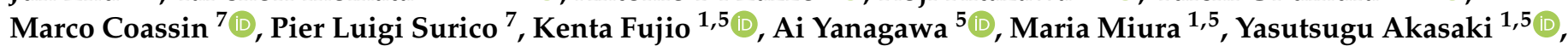 \\ Keiichi Fujimoto ${ }^{5,6}$, Ken Nagino ${ }^{4}$, Akie Midorikawa-Inomata ${ }^{4}$, Kunihiko Hirosawa ${ }^{1,5}{ }^{10}$, Mizu Kuwahara ${ }^{1,5}$, \\ Tianxiang Huang ${ }^{1,5}$, Hurramhon Shokirova ${ }^{1}$, Atsuko Eguchi ${ }^{4}\left(\mathbb{D}\right.$ and Akira Murakami ${ }^{1,5,6}$ (D)
}

Citation: Zhu, J.; Inomata, T.; Di Zazzo, A.; Kitazawa, K.; Okumura, Y.; Coassin, M.; Surico, P.L.; Fujio, K.; Yanagawa, A.; Miura, M.; et al. Role of Immune Cell Diversity and Heterogeneity in Corneal Graft Survival: A Systematic Review and Meta-Analysis. J. Clin. Med. 2021, 10, 4667. https://doi.org/10.3390/ jcm10204667

Academic Editor: Margaret M. DeAngelis

Received: 15 August 2021

Accepted: 8 October 2021

Published: 12 October 2021

Publisher's Note: MDPI stays neutral with regard to jurisdictional claims in published maps and institutional affiliations.

Copyright: () 2021 by the authors Licensee MDPI, Basel, Switzerland. This article is an open access article distributed under the terms and conditions of the Creative Commons Attribution (CC BY) license (https:// creativecommons.org/licenses/by/ $4.0 /)$.
1 Department of Ophthalmology, Juntendo University Graduate School of Medicine, Tokyo 1130033, Japan; j.zhu.gx@juntendo.ac.jp (J.Z.); y-okumura@juntendo.ac.jp (Y.O.); k.fujio.zz@juntendo.ac.jp (K.F.); maria-k@juntendo.ac.jp (M.M.); y-akasaki@juntendo.ac.jp (Y.A.); k-hirosawa@juntendo.ac.jp (K.H.); mz-ohno@juntendo.ac.jp (M.K.); h.tianxiang.zb@juntendo.ac.jp (T.H.); h-shokirova@juntendo.ac.jp (H.S.); amurak@juntendo.ac.jp (A.M.)

2 Department of Ophthalmology, Subei People's Hospital of Jiangsu Province, Yangzhou 225001, China

3 Department of Strategic Operating Room Management and Improvement, Juntendo University Graduate School of Medicine, Tokyo 1130033, Japan

4 Department of Hospital Administration, Juntendo University Graduate School of Medicine, Tokyo 1130033, Japan; k-nagino@juntendo.ac.jp (K.N.); ak-inomata@juntendo.ac.jp (A.M.-I.); a-eguchi@juntendo.ac.jp (A.E.)

5 Department of Digital Medicine, Juntendo University Graduate School of Medicine, Tokyo 1130033, Japan; miya-ai@juntendo.ac.jp (A.Y.); k-fujimoto@juntendo.ac.jp (K.F.)

6 Department of Ophthalmology, Faculty of Medicine, Juntendo University, Tokyo 1130033, Japan

7 Ophthalmology Complex Operative Unit, Campus Bio-Medico University Hospital, 00128 Rome, Italy; antoniodizazzo@gmail.com (A.D.Z.); m.coassin@unicampus.it (M.C.); pierluigi.surico@unicampus.it (P.L.S.)

8 Department of Ophthalmology, Kyoto Prefectural University of Medicine, Kyoto 6020841, Japan; kkitazaw@koto.kpu-m.ac.jp

9 Buck Institute for Research on Aging, Novato, CA 94945, USA

* Correspondence: tinoma@juntendo.ac.jp; Tel.: +81-3-5802-1228

Abstract: Corneal transplantation is one of the most successful forms of solid organ transplantation; however, immune rejection is still a major cause of corneal graft failure. Both innate and adaptive immunity play a significant role in allograft tolerance. Therefore, immune cells, cytokines, and signal-transduction pathways are critical therapeutic targets. In this analysis, we aimed to review the current literature on various immunotherapeutic approaches for corneal-allograft rejection using the PubMed, EMBASE, Web of Science, Cochrane, and China National Knowledge Infrastructure. Retrievable data for meta-analysis were screened and assessed. The review, which evaluated multiple immunotherapeutic approaches to prevent corneal allograft rejection, showed extensive involvement of innate and adaptive immunity components. Understanding the contribution of this immune diversity to the ocular surface is critical for ensuring corneal allograft survival.

Keywords: corneal transplantation; immune cell; diversity; heterogeneity; innate immunity; adaptive immunity; systematic review; meta-analysis

\section{Introduction}

Corneal transplantation has been proven to be the most effective therapy for corneal disorders such as opacity, keratoconus, corneal degeneration, scarring due to keratitis, trauma, and any physio-pathological changes on the ocular surface [1-3]. In addition to the appropriate examination of the characteristics of the donor and the tissue [4], immune privilege plays an important role in the success of corneal transplantation procedures $[5,6]$.

Corneal immune and angiogenic privilege [7] is crucial to the success of corneal transplantation and is mainly dependent on resident heterogeneous immune cells, including 
dendritic cells (DCs), Langerhans cells (LCs), mast cells, macrophages, T lymphocytes, and regulatory $\mathrm{T}$ cells [8-11]. Additionally, the systemic immune response in certain autoimmune diseases (such as Sjögren's syndrome, systemic lupus erythematosus, and rheumatoid arthritis) affects the homeostasis of the ocular surface immune microenvironment, leading to the loss of corneal avascularity [12,13]. The underlying mechanism involves various components of the immune system [14]. Consequently, immunological approaches have been introduced to improve corneal graft survival. Conventional prophylaxis, including topical or systemic medications such as corticosteroids, cyclosporine A, and tacrolimus, has been proven to be successful [15-17]. Although immunosuppressive drugs show promising effectiveness, their side effects such as cataracts, susceptibility to infection, and glaucoma cannot be disregarded $[18,19]$. Several studies have been conducted on immunotherapy for corneal transplantation focusing on immune checkpoint inhibitors, human leukocyte antigen (HLA)-matching strategy, and immunomodulatory cytokines [20-22]. These studies give extraordinary contributions to the management of corneal graft rejections.

In this review, various immunotherapies for corneal transplantation were assessed to explore the effects on different immune cell populations, relative cytokines, and signaling pathways involved in graft survival. The results from this study could represent a guide for further independent studies focusing on alternative immunotherapy strategies for corneal transplantation.

\section{Materials and Methods}

\subsection{Database Retrieval and Search Strategy}

Electronic bibliographic databases including PubMed, EMBASE, Cochrane, Web of Science, and China National Knowledge Infrastructure were used to collect published research papers (from January 1988 to December 2020), by combining the genetic terms. The final formula was as follows: [(corneal transplant) OR (corneal transplantation) OR (corneal grafts) OR (keratoplasty) OR (corneal allografts) OR (corneal graft survival) OR (corneal allograft survival) OR (keratoplasty survival)] AND [(innate) OR (adaptive) OR (immune) OR (innate immune) OR (adaptive immune)]. The design of this study followed the guidelines of the Preferred Reporting Items for Systematic Reviews and Meta-Analyses (PRISMA) protocols [23]. The published languages were limited to English, Chinese, and German. The search results were screened for suitable topics and full articles accessible for systematic review. Full-text articles containing integral data for meta-analysis were collected. The study inclusion and exclusion criteria are presented in Table 1. Search results were compiled using EndNote X9.3.2 (Clarivate Analytics, Philadelphia, PA, USA). In keeping with the quality standards for reporting systematic reviews and meta-analyses of observational studies [24], two independent researchers (J.Z. and T.I.) screened the retrieved articles. The same investigators independently assessed the full text of the records that were deemed eligible in consensus.

Table 1. Inclusion and exclusion criteria for meta-analysis.

\section{Inclusion criteria}

Study objective: corneal survival or rejection data from murine allogeneic corneal transplantation experiment; various intervention factors were investigated

Study design: experimental research using the murine (mice or rat) corneal allograft model, studied using the valid data of experimental and control groups

Outcome: evaluation of allograft survival from innate and adaptive immunity perspective, case number, mean survival or rejection days with standard deviation, survival or rejection rate, and follow-up duration

Exclusion criteria

Experimental methods and protocols, reviews, systematic reviews, and conference proceedings 
Table 1. Cont.

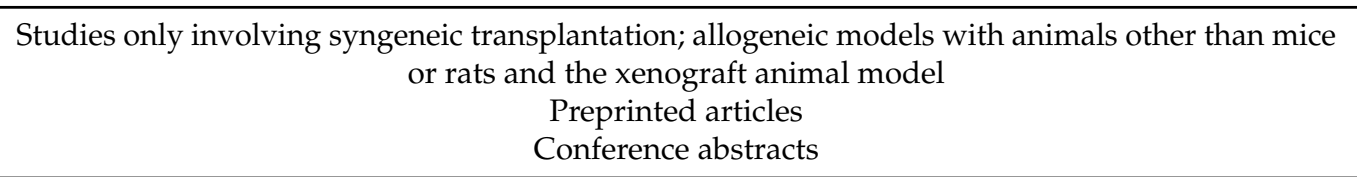

\subsection{Data Extraction}

Two independent reviewers (J.Z. and T.I.) extracted data from each eligible study using a standardized data-extraction sheet and subsequently cross-checked the results. Disagreements between the reviewers regarding the extracted data were resolved through discussion with a third reviewer (Y.O.). The following data were extracted: author's first name, date of publication, details of intervention in the study and control groups, sample size, mean survival or rejection days and standard deviation (SD), follow-up period and main results, and survival or rejection ratio of the mouse or rat corneal allografts. The unit of analysis was corneal allograft.

\subsection{Statistical Analysis}

Analysis was performed using OpenMetaAnalyst version 12.11.14 (available online: http: / / www.cebm.brown.edu/openmeta/, accessed on 6 October 2021) [25]. The study weight was calculated using the Mantel-Haenszel method. Statistical heterogeneity was assessed using Cochran's Q and $I^{2}$ tests. $I^{2}$ represents the percentage of total variation across trials, which accounts for heterogeneity. As there was no heterogeneity $\left(I^{2}<50 \%\right)$ among the studies, a fixed-effects model was applied. When $I^{2}$ was $<50 \%$, a random-effects analysis was performed.

\section{Results}

\subsection{Study Characteristics}

The articles included in this systematic review were published between 1 January 1988, and 31 December 2020. In total, 1307 studies were selected according to the search strategy, 995 studies were excluded owing to irrelevant titles or topics, and 264 studies with human subjects or other animal models were excluded. Thirty articles were finally included in the meta-analysis (Figure 1). Of these, 11 articles were from the United States [26-36], 10 from China [37-46], seven from Germany [47-53], and one each from France [54] and Portugal [55]. Altogether, 845 corneal allografts were identified in these studies (Table 2). Twelve studies used a rat allograft model, whereas eighteen studies used a mouse allograft model. Fifteen studies reported the mean survival or rejection days, one study reported median survival days, all thirty studies reported the survival or rejection rate, and one study reported immunoreaction days. 
Table 2. Characteristics of studies included in the meta-analysis.

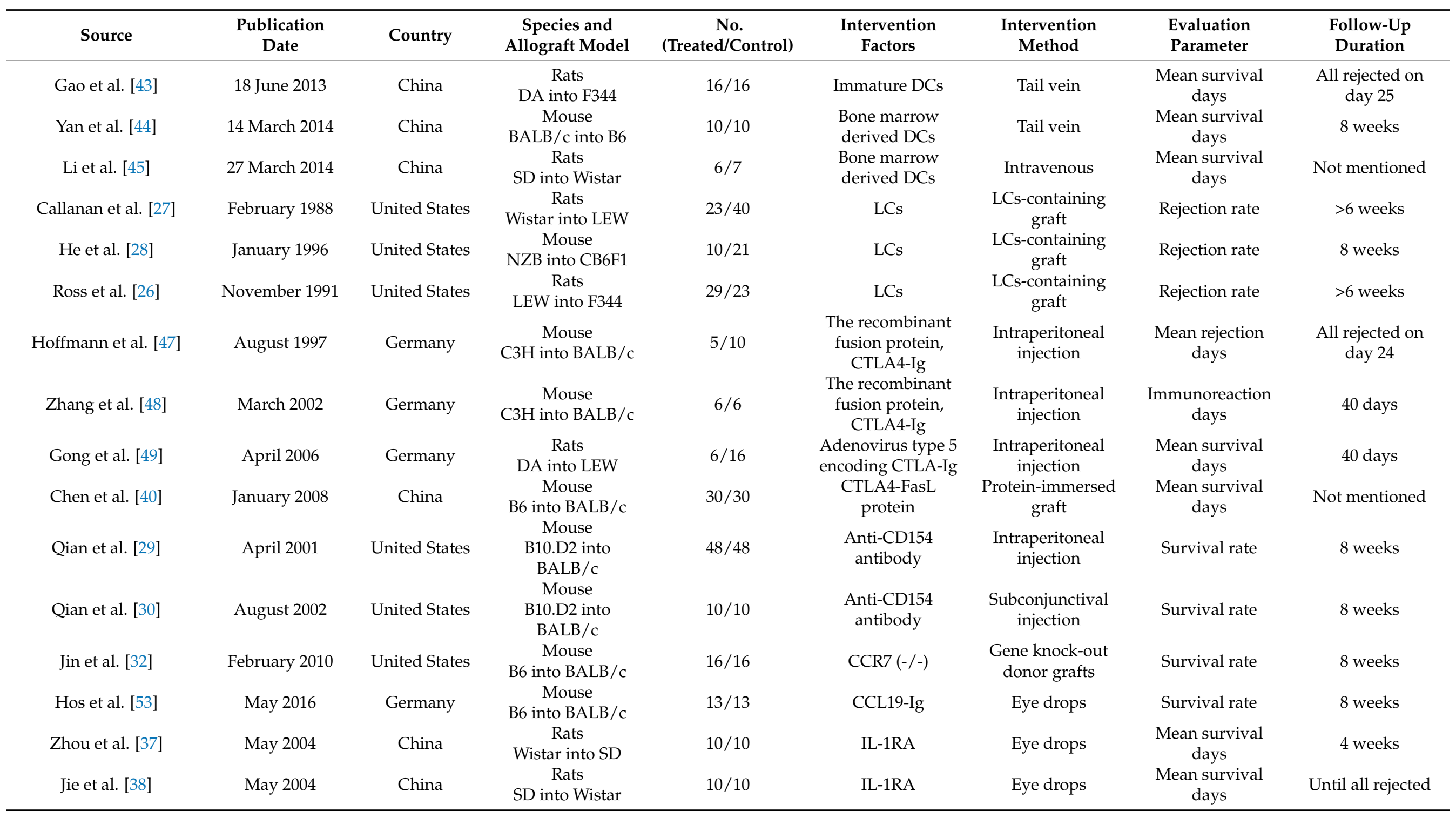


Table 2. Cont.

\begin{tabular}{|c|c|c|c|c|c|c|c|c|}
\hline Source & $\begin{array}{c}\text { Publication } \\
\text { Date }\end{array}$ & Country & $\begin{array}{c}\text { Species and } \\
\text { Allograft Model }\end{array}$ & $\begin{array}{c}\text { No. } \\
\text { (Treated/Control) }\end{array}$ & $\begin{array}{l}\text { Intervention } \\
\text { Factors }\end{array}$ & $\begin{array}{l}\text { Intervention } \\
\text { Method }\end{array}$ & $\begin{array}{l}\text { Evaluation } \\
\text { Parameter }\end{array}$ & $\begin{array}{l}\text { Follow-Up } \\
\text { Duration }\end{array}$ \\
\hline Jie et al. [39] & December 2004 & China & $\begin{array}{c}\text { Rats } \\
\text { F344 into LEW }\end{array}$ & $8 / 10$ & IL-1RA & $\begin{array}{l}\text { Subconjunctival } \\
\text { injection }\end{array}$ & $\begin{array}{l}\text { Mean survival } \\
\text { days }\end{array}$ & Until all rejected \\
\hline Torres et al. [55] & 18 August 1998 & Portugal & $\begin{array}{c}\text { Rats } \\
\text { PVG into AO }\end{array}$ & $7 / 6$ & Interleukin-10 & $\begin{array}{l}\text { Subconjunctival } \\
\text { injection }\end{array}$ & $\begin{array}{c}\text { Mean rejection } \\
\text { days }\end{array}$ & Until all rejected \\
\hline Gong et al. [50] & $\begin{array}{c}9 \text { November } \\
2006\end{array}$ & Germany & $\begin{array}{c}\text { Rats } \\
\text { Wistar to LEW }\end{array}$ & $6 / 9$ & Interleukin-10 & $\begin{array}{l}\text { IL-10 gene transfer } \\
\text { graft }\end{array}$ & $\begin{array}{c}\text { Mean rejection } \\
\text { days }\end{array}$ & Until all rejected \\
\hline Cunnusamy et al. [33] & 15 October 2010 & United States & $\begin{array}{c}\text { Mouse } \\
\text { B6 into BALB/c }\end{array}$ & $10 / 10$ & $\begin{array}{l}\text { Anti-IL-17A } \\
\text { antibody }\end{array}$ & $\begin{array}{l}\text { Intraperitoneal } \\
\text { injection }\end{array}$ & $\begin{array}{c}\text { Mean rejection } \\
\text { days }\end{array}$ & 8 weeks \\
\hline Cunnusamy et al. [34] & 15 June 2011 & United States & $\begin{array}{c}\text { Mouse } \\
\text { B6 into BALB/c }\end{array}$ & $10 / 10$ & $\begin{array}{l}\text { Anti-IL-17A } \\
\text { antibody }\end{array}$ & $\begin{array}{l}\text { Intraperitoneal } \\
\text { injection }\end{array}$ & $\begin{array}{c}\text { Mean rejection } \\
\text { days }\end{array}$ & 8 weeks \\
\hline He et al. [41] & November 2010 & China & $\begin{array}{c}\text { Mouse } \\
\text { B6 into BALB/c }\end{array}$ & $10 / 10$ & $\begin{array}{l}\mathrm{CD} 4^{+} \mathrm{CD} 25^{+} \mathrm{T} \\
\text { cells }\end{array}$ & $\begin{array}{l}\text { Retroorbital } \\
\text { injection }\end{array}$ & $\begin{array}{c}\text { Median survival } \\
\text { days }\end{array}$ & $\begin{array}{l}\text { All rejected on } \\
\text { day } 29\end{array}$ \\
\hline Xu et al. [46] & $\begin{array}{c}15 \text { November } \\
2015\end{array}$ & China & $\begin{array}{c}\text { Mouse } \\
\text { B6 into BALB/c }\end{array}$ & $6 / 6$ & $\begin{array}{l}\text { TGF- } \beta \text {-induced } \\
\text { regulatory T cells }\end{array}$ & $\begin{array}{l}\text { Subconjunctival } \\
\text { injection }\end{array}$ & $\begin{array}{l}\text { Mean survival } \\
\text { days }\end{array}$ & 8 weeks \\
\hline Cursiefen et al. [31] & August 2004 & United States & $\begin{array}{c}\text { Mouse } \\
\text { B6 into BALB/c }\end{array}$ & $22 / 22$ & $\begin{array}{l}\text { Molecular trap for } \\
\text { VEGF-A }\end{array}$ & $\begin{array}{l}\text { Intraperitoneal } \\
\text { injection }\end{array}$ & Survival rate & 8 weeks \\
\hline Hos et al. [51] & May 2008 & Germany & $\begin{array}{c}\text { Mouse } \\
\text { B6 into BALB/c }\end{array}$ & $11 / 11$ & $\begin{array}{l}\text { VEGFR-Tyrosine } \\
\text { kinase inhibitor }\end{array}$ & $\begin{array}{l}\text { Intraperitoneal } \\
\text { injection }\end{array}$ & Survival rate & 8 weeks \\
\hline Bachmann et al. [52] & August 2009 & Germany & $\begin{array}{c}\text { Mouse } \\
\text { B6 into BALB/c }\end{array}$ & $11 / 11$ & $\begin{array}{c}\text { Molecular trap for } \\
\text { VEGF-A }\end{array}$ & $\begin{array}{l}\text { Intraperitoneal } \\
\text { injection }\end{array}$ & Survival rate & 8 weeks \\
\hline Rocher et al. [54] & January 2011 & France & $\begin{array}{c}\text { Rats } \\
\text { BN into LEW }\end{array}$ & $6 / 6$ & $\begin{array}{l}\text { Anti-VEGF } \\
\text { antibody }\end{array}$ & $\begin{array}{l}\text { Subconjunctival } \\
\text { injection }\end{array}$ & Survival rate & Day $21 *$ \\
\hline Cho et al. [35] & December 2012 & United States & $\begin{array}{c}\text { Mouse } \\
\text { B6 into BALB/c }\end{array}$ & $16 / 11$ & $\begin{array}{l}\text { VEGR-1- } \\
\text { morpholino }\end{array}$ & $\begin{array}{l}\text { Subconjunctival } \\
\text { injection }\end{array}$ & Survival rate & 8 weeks \\
\hline Emami-Naeini et al. [36] & November 2014 & United States & $\begin{array}{c}\text { Mouse } \\
\text { B6 into BALB/c }\end{array}$ & $16 / 10$ & Soluble VEGFR-3 & $\begin{array}{l}\text { Intraperitoneal } \\
\text { injection }\end{array}$ & Survival rate & 8 weeks \\
\hline
\end{tabular}

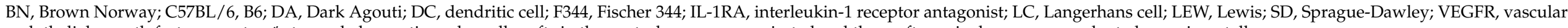
endothelial growth factor receptor; * stopped observation when all grafts in the control group were rejected and the graft survival score was evaluated experimentally. 


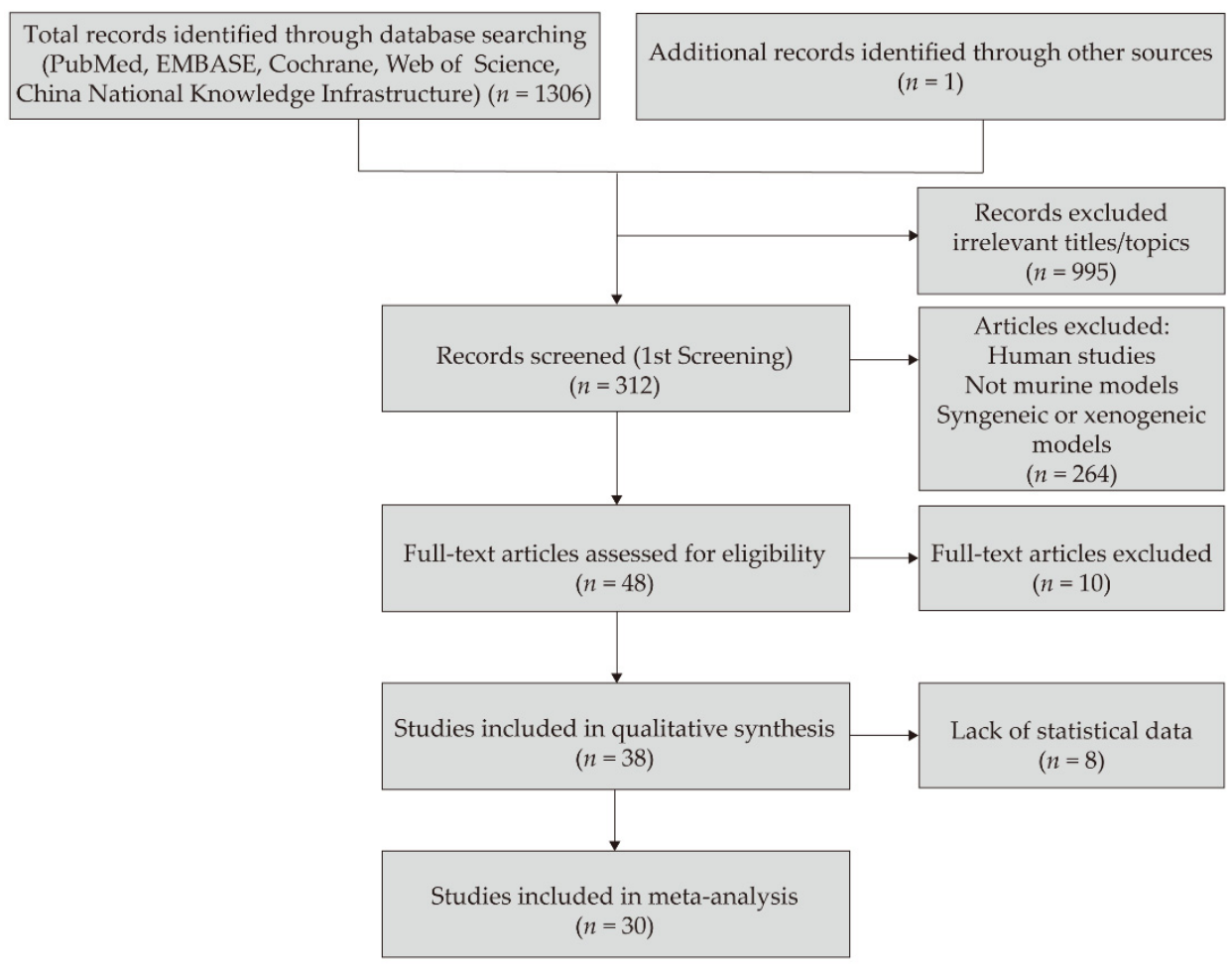

Figure 1. Flow chart of the studies selected for meta-analysis.

\subsection{Immune Cells, Cytokines, and Pathways Associated with Allograft Rejection and Survival}

The 30 studies selected for meta-analysis covered mainstream research directions for immune therapy for corneal transplantation. The number of research papers in descending order were as follows: anti-VEGF therapy (6) > DCs and LCs (6: 3 for each) > IL-1RA (4), CLTA-4 Ig therapy (4) > anti-IL-17 antibody (2), IL-10 (2), anti-CD154 antibody (2), CCR7-CCL19 blockade (2), and regulatory T cells (2). Among these immunotherapies, immature dendritic cell intervention presented the longest mean difference in survival time by 14.61 days, and IL-17 had a protective role with a mean difference of 10.98 days. Regulatory $\mathrm{T}$ cells also demonstrated a strong promotion for graft privilege with a mean difference of 9.42 days.

\subsubsection{T-Cell Subsets in Corneal-Allograft Rejection}

The role of $\mathrm{CD}^{+}$and $\mathrm{CD} 8^{+} \mathrm{T}$ cells in alloantigen recognition is implied in the initiation of rejection [56,57]. In this review, the respective contributions of these two cell subsets in murine corneal-allograft rejection were investigated. Six studies [58-63] used anti-CD4 antibodies in murine corneal transplantation. While four studies showed that systemic or local administration of anti-CD4 antibodies could reduce the rejection rate, two of these studies $[59,61]$ reported that anti-CD8 antibody administration did not reduce the rejection rate of corneal allografts. Two other studies $[64,65]$ examined the role of $\mathrm{CD}^{+} \mathrm{T}$ cells in allograft rejection and found that $\mathrm{CD}^{+} \mathrm{T}$ cell-mediated rejection had a slow tempo and $\mathrm{CD}^{+} \mathrm{T}$ cells were not essential in promoting corneal-graft rejection. Together, these results showed that $\mathrm{CD}^{+} \mathrm{T}$ cells play a major role in allograft rejection.

\subsubsection{Dendritic Cell Heterogeneity in Different Roles of Corneal Allograft Tolerance}

DCs are potent antigen-presenting cells (APCs) with various subsets and different states. Immature DC attributes were evaluated in relation to corneal allograft tolerance in a total of 65 eyes across three studies [43-45]. Given immature DC intervention, the mean difference in survival time was significantly prolonged by 14.61 days (95\% CI, 8.55 to 20.69; $P<0.001$ ) (Figure 2A). The role of LCs, a distinct population of DCs, in corneal- 
allograft rejection was also evaluated; three papers with 146 cases were reviewed [26-28]. Compared with the control grafts (treated with immature DCs), those with donor-derived LCs exhibited a significantly increased rejection rate (odds ratio $(\mathrm{OR})=4.94(95 \% \mathrm{CI}, 2.48$ to 9.84)) (Figure 2B).

A

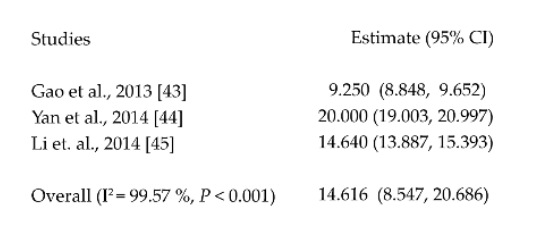

B

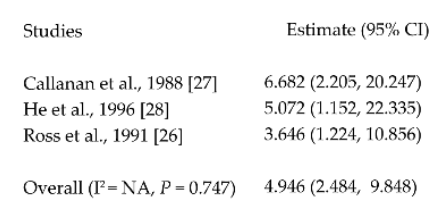

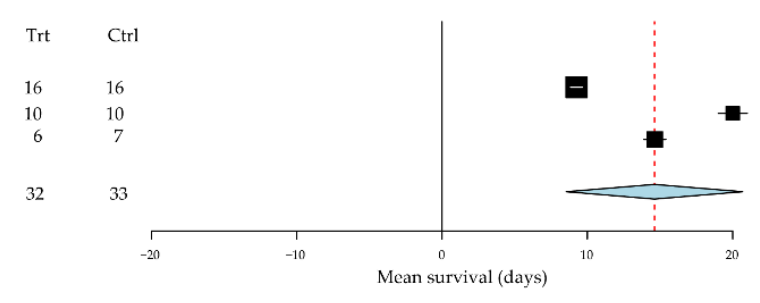

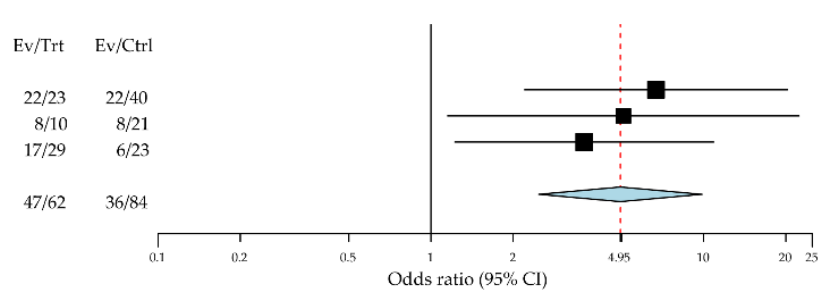

Figure 2. The role of the dendritic cells in allograft survival. (A) Immature dendritic cells promote allograft survival; (B) Langerhans cells increase the allograft rejection rate. CI, confidence intervals; EV, event; Trt, treatment; Ctrl, control.

\subsubsection{Macrophages Contribute to the Immunopathogenesis of Corneal-Graft Rejection}

In addition to the predominant effect of $T$ lymphocytes on allograft rejection, the involvement of macrophages in grafted corneas was reviewed. Six studies [66-71] on the effects of macrophages on corneal-allograft survival were included; their results showed the increased number of macrophages and the production of Th1 cytokines, interferon- $\gamma$ (IFN- $\gamma$ ), interleukin-2 (IL-2), IL-12, IL-1, tumor necrosis factor-alpha (TNF- $\alpha$ ), C-C motif chemokine ligand 3 (CCL3), and inducible nitric oxide synthase (iNOS), which were observed in rejected grafts compared to controls. Macrophages play a role in the early phase of corneal-allograft rejection. Maruyama et al. [66] found that CD11b+ macrophages are critical for the development of inflammation-dependent lymphangiogenesis in the eye. Using macrophage depletion or CD11b-/- or F4/80-/- mouse models could lead to fewer lymphatic vessels and less lymphangiogenesis, providing immune privilege to the grafts. Yamada et al. [71] reported that enhanced graft acceptance might be attributed to the suppression of alloantigen-induced Th1 polarization through the induction of macrophages with reduced intracellular glutathione levels. Together, these results suggest that macrophages are non-negligible components in the immunopathogenesis of corneal graft rejection.

\subsubsection{Cytokine Diversity in the Regulation of Corneal-Allograft Rejection}

Although numerous immune cells and their cytokine production are involved in the corneal-allograft immune reaction, few studies have generated statistical data for metaanalysis under a unified standard assessment. The representative data analysis is as follows: four studies with a total of 98 cases were included in the assessment of the effect of IL-1 receptor antagonist (IL-1RA) on corneal allografts [37-39,42]. The mean survival time was significantly prolonged in the IL-1RA intervention groups compared to the control group, with a mean difference of 3.65 days ( $95 \% \mathrm{CI}, 2.30$ to $5.01, P<0.001$ ) (Figure $3 \mathrm{~A}$ ). 
A

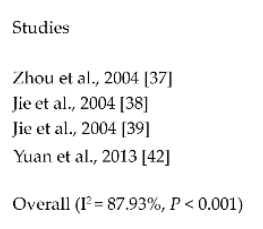

Estimate $(95 \% \mathrm{Cl})$
$4.000(2.790,5.210)$
$3.200(1.658,4.742)$
$2.450(1.756,3.144)$
$4.910(4.218,5.602)$
$3.654(2.297,5.011)$

Trt
10
10
8
20
48

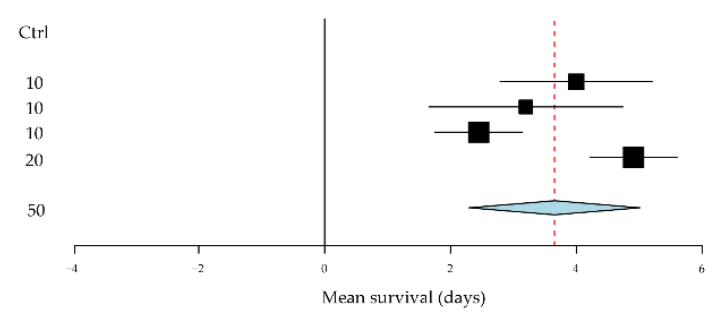

B

Studies

Cunnusamy et al., 2010 [33] Cunnusamy et al., 2011 [34]

Overall $\left(l^{2}=0 \%, P=0.477\right)$

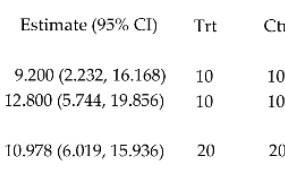

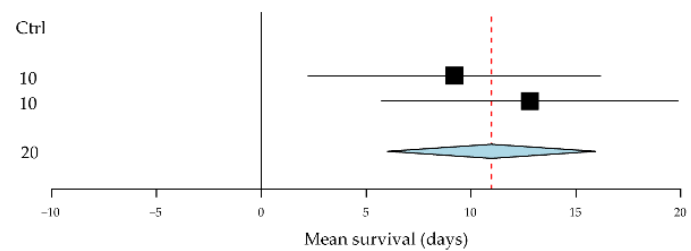

C

Studies

Cursiefen et al., 2004 [31]

Hos et al., 2008 [51]

Bachmann et al., 2009 [52]

Rocher et al., 2011 [54]

Cho et al., 2012 [35]

Emami-Naeini et al., 2014 [36]

Overall $\left(I^{2}=\mathrm{NA}, P=0.983\right)$

\begin{abstract}
Estimate $(95 \% \mathrm{Cl})$
$4.350(1.326,14.272)$ $2.833(0.553,14.503)$ $4.403(0.627,30.900)$ $7.029(0.752,65.674)$ $2.996(0.276,32.507)$ $.251(1.090,35.850)$

$4.332(2.155,8.710)$
\end{abstract}
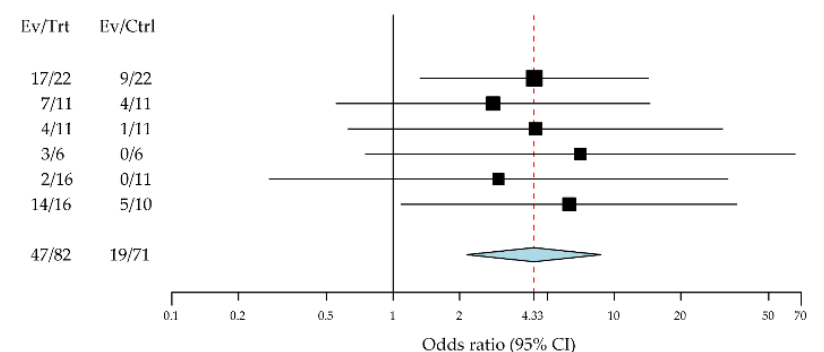

D

Studies

Torres et al., 1999 [55] Gong et al., 2006 [49]

Overall $\left(I^{2}=95.6 \%, P<0.001\right)$

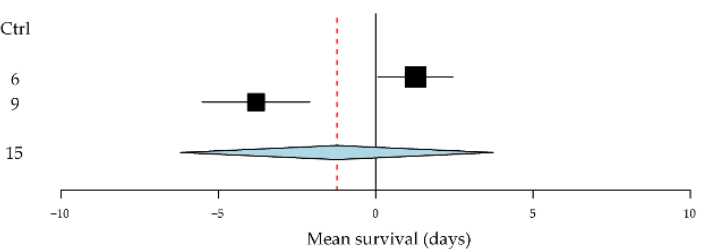

Figure 3. Effects of cytokines in immunotherapies for corneal allografts. (A) IL-1RA promotes allograft survival. (B) Anti-IL-17 antibody increased allograft rejection. (C) Anti-VEGF improves allograft survival rate. (D) Local administration of IL-10 did not improve allograft survival. CI, confidence intervals; EV, event; Trt, treatment; Ctrl, control.

Two studies with a total of 40 cases were included in the assessment of the effect of IL-17 on corneal allografts $[33,34]$. The mean rejection days were significantly reduced in the anti-IL-17 antibody intervention groups compared to the control group, with a mean difference of 10.98 days (95\% CI, 6.01 to $15.94 ; P<0.001)$ (Figure 3B). It is suggested that IL-17 may contribute to the immune privilege of corneal allografts.

Six studies with a total of 153 cases were included in the assessment of the effect of vascular endothelial growth factor (VEGF) on corneal allografts $[31,35,36,51,52,54]$. Allograft survival rates were significantly higher in the anti-VEGF intervention groups compared to the control group, with an OR of 4.33 (95\% CI, 2.16 to 8.71) (Figure 3C).

Two studies with a total of 28 cases were included in the assessment of the effect of IL-10 on corneal allografts $[50,55]$. No significant difference was found in the intervention groups compared to the control group. The standardized mean difference was 1.23 days (95\% CI, -6.20 to $3.73, P=0.627$ ) (Figure 3D). 


\subsubsection{Co-Stimulatory Pathways in Corneal-Allograft Survival}

In addition to the classic T-cell receptor (TCR) and major histocompatibility complex (MHC) interactions that initiate T cell activation, we investigated the function of several representative costimulatory signaling pathways in corneal-allograft survival [40,47-49]. For the B7-CTLA-4 interaction, we reviewed four studies including 109 cases [40,47-49]. The mean survival time was significantly higher in the CLTA-4 Ig intervention groups than in the control group, with a mean difference of 4.08 days ( $95 \%$ CI, 3.33 to $4.82, P<0.001$ ) (Figure 4A).

A

Studies

Hoffmann et al., 1997 [47]

Zhang et al., 2002 [48]

Gong et al., 2006 [49]

Chen et al., 2008 [40]

Overall $\left(I^{2}=0 \%, P<0.001\right)$

B

Studies

Qian et al., 2001 [29]

Qian et al., 2002 [30]

Overall $\left(I^{2}=\mathrm{NA}, P=0.435\right)$
Estimate $(95 \% \mathrm{CI})$
$2.560(1.149,3.972)$
$1.646(0.337,2.955)$
$6.544(4.395,8.694)$
$7.318(5.914,8.722)$
$4.077(3.333,4.820)$

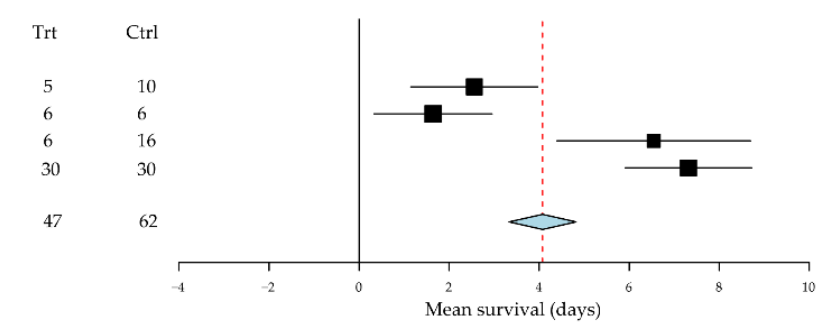

Estimate $(95 \% \mathrm{Cl})$

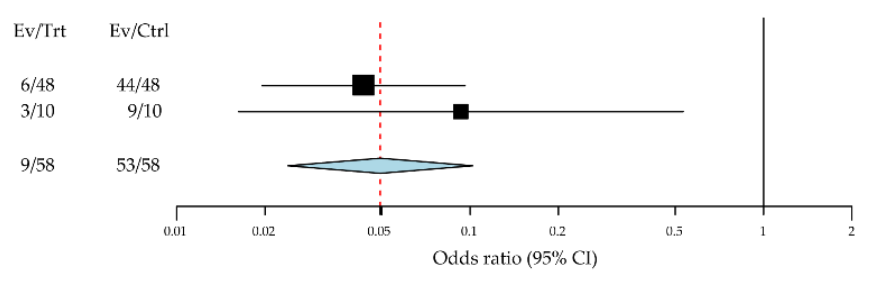

C

Studies

Jin et al., 2010 [32]

Hos et al., 2016 [53]

Overall $\left(I^{2}=\mathrm{NA}, P=0.574\right)$
$0.043(0.020,0.096)$ $0.093(0.016,0.532)$ $0.049(0.024,0.102)$

$$
\begin{aligned}
& \text { Estimate }(95 \% \mathrm{CI}) \\
& 0.407(0.089,1.856) \\
& 0.220(0.048,1.011)
\end{aligned}
$$

$0.300(0.102,0.879)$

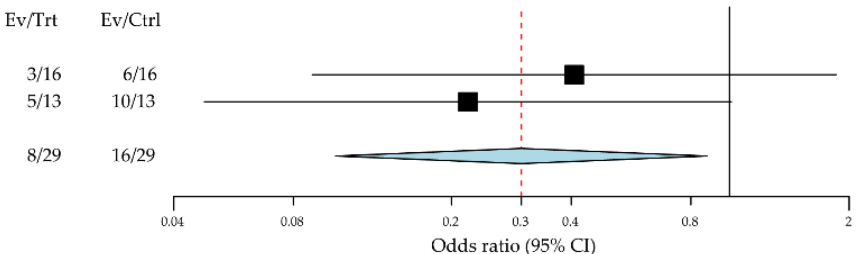

Figure 4. Blockage of co-stimulatory pathways influences corneal-allograft survival. (A) CLTA-4 Ig promotes allograft survival. (B) Anti-CD154 antibody increases the allograft survival rate. (C) CCR7-CCL19 blockade improves the allograft survival rate. CI, confidence intervals; EV, event; Trt, treatment; Ctrl, control.

For the CD40-CD154 pathway, we reviewed two studies including 116 cases [29,30]. The survival rates were significantly higher in the anti-CD154 antibody intervention groups than in the control group (OR $=0.05 ; 95 \% \mathrm{CI}, 0.03$ to $0.10 ; P<0.001)$ (Figure $4 \mathrm{~B})$.

For the C-C chemokine receptor type 7 (CCR7)-CC-chemokine ligand 19 (CCL19) pathway, we reviewed two studies including 58 cases [32,53]. The survival rates were significantly higher when CCR7-CCL19 was blocked using CCL19 Ig or CCR7-/- mouse models than the survival rate in the control group $(\mathrm{OR}=0.30 ; 95 \% \mathrm{CI}, 0.10$ to $0.88 ; P=0.028)$ (Figure 4C).

\subsubsection{Regulatory T Cells (Tregs) Promote Corneal Allograft Survival}

Tregs are a subset of $\mathrm{CD} 4^{+} \mathrm{T}$ cells with highly expressed $\mathrm{CD} 4^{+} \mathrm{CD} 25^{+}$surface markers [72]; numerous studies have reported their immunosuppressive function in organ transplantation. In this review, two papers including thirty-two cases were assessed [41,46]. The mean survival time was significantly prolonged in the Treg intervention groups com- 
pared with that in the PBS control group, with a standard mean difference of 9.42 days (95\% CI, 4.14 to $14.70 ; P<0.001$ ) (Figure 5).

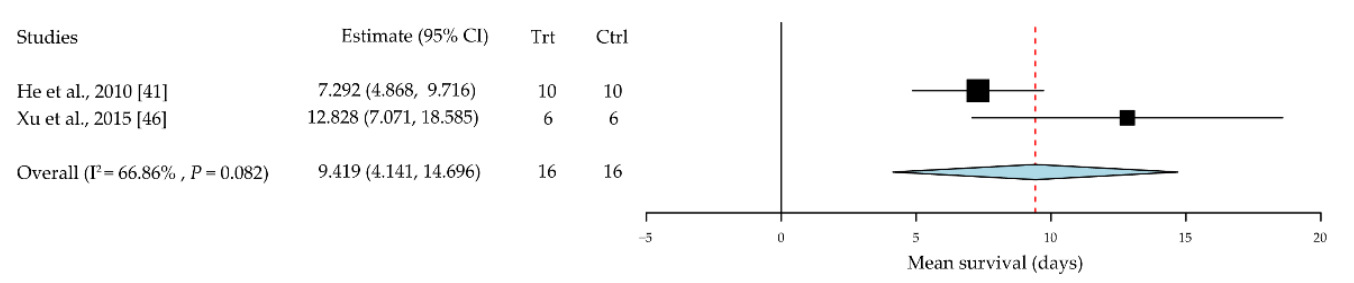

Figure 5. Regulatory T cells prolong corneal allograft survival. CI, confidence intervals; EV, event; Trt, treatment; Ctrl, control.

\section{Discussion}

Immune privilege is critical to the survival of corneal transplants and includes lymphangiogenic and hemangiogenic privilege, which prevents blood and lymphatic vessels from invading the cornea. This privilege maintains the transparency of corneal tissue, which provides visual functions. During the inflammation process, inflammatory cells and their products such as cytokines and growth factors could be delivered through the blood and lymphatic vessels, leading to the immune rejection.

The process of corneal-allograft survival requires a delicate balance between immune and inflammatory reactions to provide the allografts with relative immune privilege.

$\mathrm{T}$ lymphocytes play a central role in the adaptive immune response and thus strongly impact the outcome of allografts [73]. The $\mathrm{CD}^{+}$and $\mathrm{CD} 8^{+} \mathrm{T}$ cell were designated for allorecognition in corneal transplantation [56]. $\mathrm{CD}^{+} \mathrm{T}$ cells have been shown to play a pivotal role in corneal-allograft rejection. In a clinical report, rapamycin, an inhibitor of a serine-threonine protein kinase, mammalian target of rapamycin complex-1, could inhibit effector $\mathrm{T}$ cell proliferation and activation; it was found to prevent $78 \%$ rejection in the first year during the management of high-risk transplant patients [18].

As major components of the innate immune system, DCs, neutrophils, macrophages, and natural killer cells are essential for protecting against pathogens and repairing tissue damage [74]. DCs also play an important role in the innate detection of pathogens and activation of the adaptive immune system [75]. Immature DCs (with lower levels of HLA-DR, CD80, CD83, and CD86), including bone-marrow-derived immunosuppressive cells [76], could induce T-cell tolerance, whereas mature DCs induce T-cell immunity [77-81]. Immature DCs were found to be associated with longer allograft survival compared with normal controls during the immune response process of corneal transplantation (Figure 2A) [45].

Another important type of APC, LCs are bone marrow-derived tissue-resident macrophages [82]. During immune and inflammatory reactions after corneal injury, LCs migrate into the central corneal epithelium along with neutrophils and monocytes $[83,84]$ and can induce cytotoxic T-cell responses towards donor MHC alloantigens in corneal grafts [85].

Yamaguchi et al. [86] found a notable up-regulation of the complement activation pathway in corneal transplantation Füst et al. [87] reported that the complement system might be activated both through the classical and alternative pathways in the aqueous humor of the patients with Fuchs' dystrophy. In addition to this, certain scholars have found that the presence of an increased concentration of C1rs-C1inh complex in tear samples [88], suggests the classical pathway of complement might be activated in the early postoperative period after penetrating keratoplasty. Previously, Zhang X et al. [89] reported that anti-CD45 antibody plus complement-mediated targeting of donor tissue is the most efficient way to deplete corneal passenger leukocytes. More recently, by applying eculizumab, a C5-blockade agent, Islam R et al. [90] introduced a potential therapy for inhibiting xenograft-induced innate inflammatory responses. Despite lacking relevant clinical studies, these data give us new ideas for high-risk corneal transplantation immunotherapeutic strategy. 
CCR7 is mainly expressed in activated B and T lymphocytes and can stimulate DC maturation and T-cell homing [91]. The chemokine CCL19 is one of the ligands (the other is CCL21) for CCR7. CCR7 can induce the movement of antigen-specific effector and central memory $\mathrm{T}$ cells move to the lymph nodes, followed by CCR7-CCL19 interaction [92]. CCR7-deficient mice show severely delayed kinetics for the antibody response, lack of contact sensitivity, and delayed-type hypersensitivity reactions [93]. Figure $4 \mathrm{C}$ shows that blockade of the CCR7-CCL19 axis could prolong mouse corneal-allograft survival. Thus, this blockade could be a potential approach for the manipulation of DC maturation during corneal transplantation.

During secondary signal transduction, the engagement of T cells and APCs depends on the interaction of CD40, which is expressed by B cells and APCs, with the CD40 ligand (CD40L, also known as CD154), which is expressed by activated T cells [94]. CD40 is a $48 \mathrm{kDa}$ transmembrane protein that is initially expressed on B cells, DCs, macrophages, and monocytes, as well as predominantly on corneal limbal epithelial cells [95,96]. CD154 could be a transmembrane protein or in its soluble form [97]. The engagement of CD40 on the DC surface can promote cytokine production, costimulatory molecule expression, and antigen presentation [98]. However, the inhibition of CD40-CD154 could suppress the secondary signal, consequently reducing allograft rejection, which is consistent with the meta-analysis results in this study (Figure 4B).

Another well-known co-stimulatory molecule pathway is the interaction between the B7 (CD80/86) family and CTLA-4. CTLA-4 is a receptor expressed by both CD4+ and CD8+ T cells, which mediates the suppression of T-cell activation. CTLA-4 interacts with CD80 and CD86 on APCs with high affinity and competes with CD28; its interaction with CD80/86 could induce co-stimulation [99]. Experimental data from articles reviewed here showed that CTLA-4 blockade could improve allograft survival (Figure 4A). Therefore, CTLA-4 could be used in an immune regulatory mechanism to inhibit the ability of APCs to stimulate naïve T cells.

Recently, owing to its immunosuppressive and tolerogenic properties, programmed death ligand-1 (PD-L1) has drawn scientists' attention as a potential therapeutic target in corneal transplantation. Nosov et al. [100] reported that local PD-L1 gene transfer in cultured corneas prolonged corneal allograft survival and attenuated graft rejection. Hori et al. [8] suggested that PD-L1-induced apoptosis is a mechanism of immune privilege of corneal allografts. Shen et al. [101] emphasized the importance of peripheral tissue-derived PD-L1 in down-regulating local immune responses in allografts. PD-L1 is constitutively expressed on endothelial cells of the cornea, iris-ciliary body, and neural retinal [102]. Sugita et al. reported that human corneal endothelial cells expressing PD-L1 suppress PD- ${ }^{+}$T helper 1 cells via a contact-dependent mechanism [103]. Although there have been no clinical trials on the application of this immune checkpoint inhibitor for corneal transplantation, Dutra et al. [104] reported a successful corneal transplant in a patient treated with Nivolumab for metastatic non-small cell lung cancer and suggested that the treatment with anti-PD1 could not be regarded as an absolute contraindication to corneal transplantation.

IL-1 is an important pro-inflammatory cytokine involved in the initiation of both innate and adaptive immune responses [105]. It has two subtypes: IL- $1 \alpha$ and IL-1 $\beta$. The former mediates the early stages of tissue injury, whereas the latter is responsible for a later inflammatory response [106]. IL-1RA is a suppressor that inhibits IL-1-mediated lymphocyte proliferation. Recombinant IL-1RA specifically inhibits IL- $1 \alpha$ and IL- $1 \beta$ activities, and its action has been verified in various inflammatory diseases [107]. In this review, recombinant IL-1RA was found to exhibit the same suppressive effect on allograft rejection (Figure 3A). In clinical research, human corneal limbal epithelial cells were cultured on the amniotic membrane stroma and the results showed that the expression of IL-1RA was upregulated [108]. This underlying mechanism offers new ideas for the clinical reduction of ocular surface inflammation after corneal transplantation. 
IL-17A is mainly produced by Th17 cells, which are a subset of the CD4+ T cell-derived population [109]. IL-17A is a pro-inflammatory cytokine implicated in the pathogenesis of inflammatory and autoimmune diseases [110-112]. Unlike other pro-inflammatory cytokines, such as IL-1, IFN- $\gamma$, and IL-6, IL-17A plays a protective role during acute corneal graft survival. In this review, a meta-analysis of two studies demonstrated that IL-17A depletion using an anti-IL-17A antibody could exacerbate corneal-allograft rejection (Figure 3B). However, Yin et al. [113] reported that prophylactic neutralization of IL-17 significantly increased corneal-allograft survival and reversed rejection in the late-term post-engraftment. Other than in the corneal allograft setting, Kwan T et al. [114] reported that IL-17 deficiency or neutralization was protective against graft rejection in a murine kidney allograft model. This suggests that IL-17 has spatiotemporal heterogeneity in corneal transplantation $[33,113,115]$.

Corneal neovascularization is mediated by VEGF $[115,116]$; VEGF-A combined with VEGF receptor 1 and VEGFR-2 can initiate neovascularization. Furthermore, VEGF plays an important pathogenic role in ocular surface disorders [116-118]. In corneal transplantation, neovascularization is the major cause of graft failure, especially in high-risk corneal grafts [73,119-121]. Accordingly, a higher graft survival rate was observed on the use of anti-VEGF antibodies or soluble VEGFR molecules to block this pathway (Figure 3C). In clinical practice, anti-VEGF therapies appear to be the most promising approach for corneal neovascularization in grave condition such as high-risk corneal transplantation. Human studies demonstrated that subconjunctival injection of bevacizumab could reduce corneal neovascularization [122-124].

Tregs are a subpopulation of a subset of thymus-derived CD4+ T cells that express high levels of IL-2R $\alpha$ (CD25); they modulate the immune system, maintain a tolerance to self-antigens, and prevent autoimmune diseases [72]. In mice, Tregs express CD25 and the transcriptional regulator forkhead box P3 (FOXP3) [121]. Tregs have been observed to be effective in preventing autoimmune diseases and delaying graft rejection [119,121,125-128]. Although their suppressive function has been reported in mouse models (Figure 5), the expansion of the Treg population continues to be difficult.

There are few clinical trials that use cell therapies or targeted antibodies for prolonging corneal graft survival, demonstrating a large gap between animal research and clinical practice. We collected and analyzed data from clinical reports on inflammatory cytokine levels after human corneal transplantation. Our results showed that TNF- $\alpha$, IFN- $\gamma$, IL- $1 \beta$, and IL-2 levels in the aqueous humor of keratoplasty rejection cases were much higher than those in cases where the grafts survived [129-133] (Figure 6).

These findings prove that above novel approaches and basic studies conducted in animal models provide promising future perspectives on the application of immunosuppression to improve the outcomes of corneal transplantations. For example, it has been reported that third-party allogeneic mesenchymal stromal cells could prevent rejection in a pre-sensitized high-risk model of corneal transplantation [134]. Moreover, our previous research has revealed the immunoregulatory effect of donor's bone-marrow-derived suppressor cells in a mouse model of high-risk corneal transplantation [76]. These cellular therapies may provide a potential method of dealing with neovascularization and graft rejection. A phase 1b clinical trial led by VISICORT (EudraCT ID is 2018-000890-60) is currently underway to test the safety and feasibility of healthy donor bone-marrow-derived mesenchymal stem cells as an immunotherapy for patients with a high risk of rejection of corneal transplants. Additionally, clinical studies have suggested that anti-VEGF drugs, including bevacizumab and aflibercept, could be a safe and efficient treatment alternative to improve the outcomes of corneal transplantation in patients. Previous reports have demonstrated that anti-VEGF therapy improved graft survival in patients who have undergone penetrating keratoplasty [135-137]. However, when considering the current immunotherapies for corneal transplantation, the diverse experimental methods in animal models and the lack of clinical trials contribute to the disconnection between basic research and clinical practice. Clinical trials using novel therapeutic strategies are required. 
A

\section{Studies}

Maier et al., 2010 [133]

Funding et al., 2006 [132]

Maier et al., 2011 [129]

Overall $\left(\mathrm{I}^{2}=77.54 \%, P=0.012\right)$

B

Studies

Funding et al., 2006 [132]

Maier et al., 2011 [129]

Overall $\left(I^{2}=47.63 \%, P=0.167\right)$

C

Studies

Maier et al., 2010 [133]

Funding et al., 2006 [132]

Overall $\left(\mathrm{I}^{2}=56.7 \%, P=0.129\right)$
Estimate $(95 \% \mathrm{CI})$

$0.780(0.316,1.244)$ $2.000(1.347,2.653)$

$1.200(0.710,1.690)$

$1.291(0.646,1.937)$
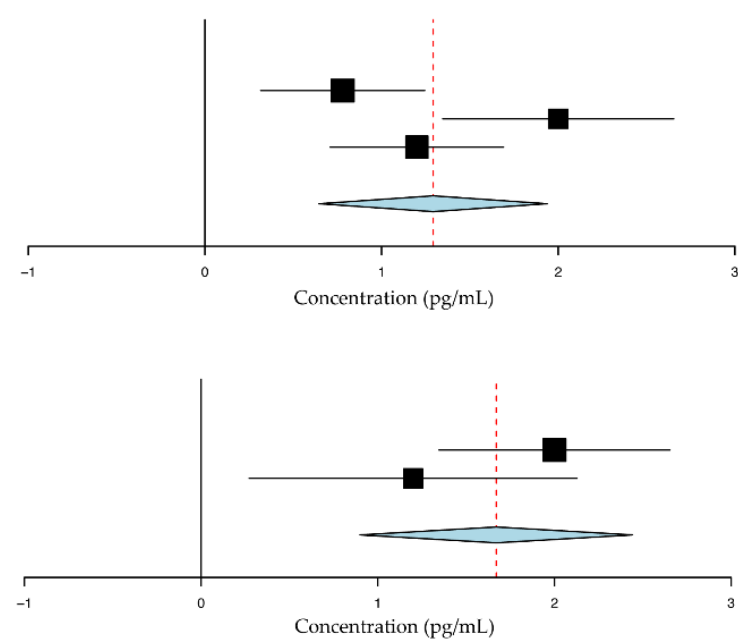

Concentration (pg/mL)

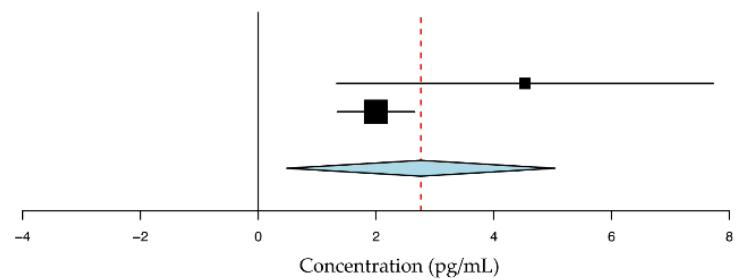

D

Studies

Maier et al., 2010 [133]

Funding et al., 2006 [132]

Maier et al., 2011 [129]

Overall $\left(I^{2}=85.4 \%, P=0.001\right)$
Estimate $(95 \% \mathrm{CI})$

$2.000(1.347,2.653)$ $1.200(0.272,2.128)$

$1.671(0.899,2.442)$

Estimate (95\% CI)

$4.530(1.333,7.727)$ $2.000(1.347,2.653)$

$2.761(0.487,5.035)$
Estimate $(95 \% \mathrm{CI})$

$0.690(0.254,1.126)$

$2.000(1.347,2.653)$

$1.700(1.121,2.279)$

$1.437(0.604,2.270)$

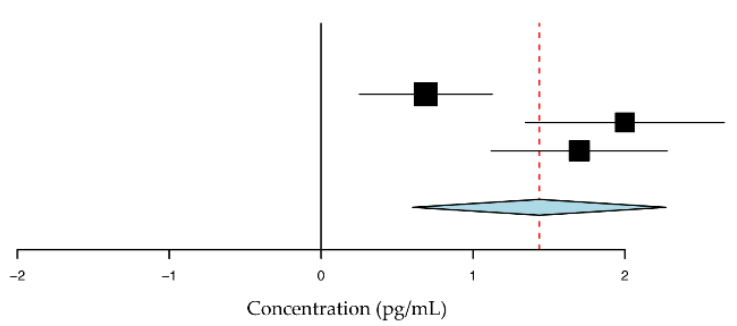

Figure 6. Inflammatory cytokine level in the aqueous humor of human corneal graft cases. (A) In the survival group, the level of TNF- $\alpha$ was $1.29 \mathrm{pg} / \mathrm{mL}$ (95\% CI, 0.65 to $1.94 \mathrm{pg} / \mathrm{mL}$ ). (B) IFN- $\gamma$ was $1.67 \mathrm{pg} / \mathrm{mL}$ (95\% CI, 0.90 to $2.44 \mathrm{pg} / \mathrm{mL}$ ), (C) IL-1 $\beta$ was $2.76 \mathrm{pg} / \mathrm{mL}$ (95\% CI, 0.49 to $5.03 \mathrm{pg} / \mathrm{mL}$ ), and (D) IL-2 was $1.44 \mathrm{pg} / \mathrm{mL}$ (95\% CI, 0.60 to $2.27 \mathrm{pg} / \mathrm{mL})$. CI, confidence intervals.

Finally, as in other tissues beyond the eye, the homeostatic equilibrium of the ocular surface is critically maintained by complex and heterogeneous parainflammatory mechanisms [138-140]. Cross-talk between APCs, T cells, and various other immune cells plays a central role in corneal graft tolerance (Figure 7). Furthermore, graft retention or graft rejection is not always directly related to immune privilege. Conditions such as trauma, infection, and endothelial corneal dystrophy could be the direct cause of corneal graft failure, altering the parainflammatory homeostatic equilibrium.

This study had certain limitations. Firstly, owing to a lack of data from clinical studies, all selected studies were based on murine allogeneic transplantation models, not humans. Second, studies were selected from the same research groups or had similar publication dates because of the small number of included studies. Third, data availability bias may exist because only graft survival was selected as an outcome, and several studies were excluded because of insufficient survival data for analysis. In addition, these reviews were limited to the penetrating keratoplasty models; other surgeries like Descemet-stripping automated endothelial keratoplasty and Descemet-membrane endothelial keratoplasty were not included. The goal of this study was to summarize a wide range of immunotherapy for corneal transplantation; it was difficult to strictly control various biases. Thus, to address these limitations, further studies are required. 


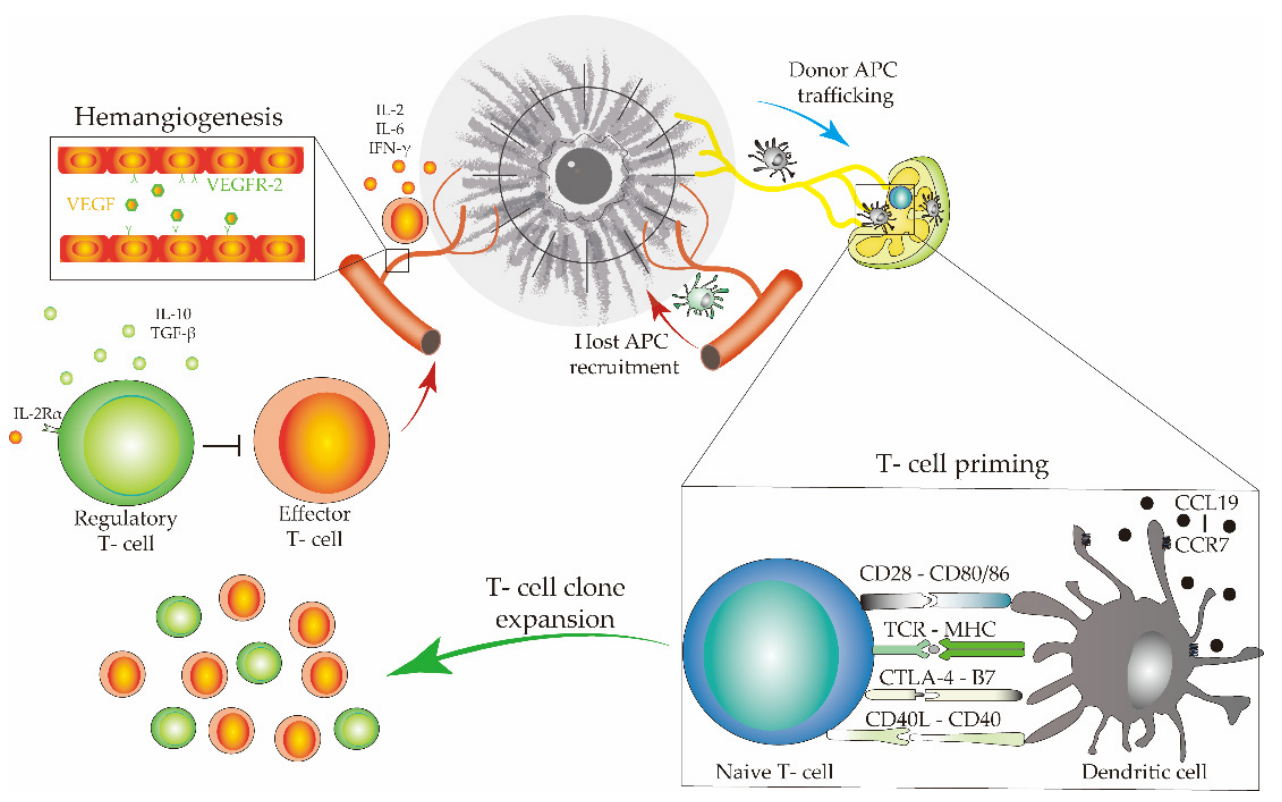

Figure 7. Cells, cell membrane receptors, ligands, and cytokines form the immune pathway involved in corneal graft survival.

\section{Conclusions}

This review demonstrates that the heterogeneity and diversity of immune response in allograft rejection, which may unveil alternative critical and effective targets for improving corneal transplantation survival.

Author Contributions: Conceptualization, T.I.; methodology, T.I. and J.Z.; validation, T.I. and J.Z.; data curation, J.Z.; writing—original draft preparation, J.Z.; writing—review and editing, T.I., A.D.Z., K.K., M.C., P.L.S.; supervision, A.M.; project administration, T.I. and J.Z.; review and suggestion: Y.O., M.C., P.L.S., K.F. (Kenta Fujio), A.Y., M.M., Y.A., K.F. (Keiichi Fujimoto), K.N., A.M.-I., K.H., M.K., T.H., H.S., A.E.; funding acquisition, T.I. All authors have read and agreed to the published version of the manuscript.

Funding: This research was funded by the Japan-China Sasakawa Medical Fellowship program, grant number 2018314, JSPS KAKENHI, Grant Numbers 16K20332, 18K16935, 20K09810, and 20K22985.

Institutional Review Board Statement: Not applicable.

Informed Consent Statement: Not applicable.

Data Availability Statement: All data generated or analyzed during this study are included in this published article.

Acknowledgments: The authors thank all members of the Department of Ophthalmology, Juntendo University Graduate School of Medicine, for providing critical comments on this manuscript.

Conflicts of Interest: The authors declare no conflict of interest.

\section{References}

1. Mathews, P.M.; Lindsley, K.; Aldave, A.J.; Akpek, E.K. Etiology of Global Corneal Blindness and Current Practices of Corneal Transplantation: A Focused Review. Cornea 2018, 37, 1198-1203. [CrossRef]

2. Williams, K.A.; Muehlberg, S.M.; Lewis, R.F.; Coster, D.J. How successful is corneal transplantation? A report from the Australian Corneal Graft Register. Eye 1995, 9 Pt 2, 219-227. [CrossRef] [PubMed]

3. Napoli, P.E.; Nioi, M.; d'Aloja, E.; Fossarello, M. The Bull's Eye Pattern of the Tear Film in Humans during Visual Fixation on En-Face Optical Coherence Tomography. Sci. Rep. 2019, 9, 1413. [CrossRef] [PubMed]

4. Napoli, P.E.; Nioi, M.; Gabiati, L.; Laurenzo, M.; De-Giorgio, F.; Scorcia, V.; Grassi, S.; d'Aloja, E.; Fossarello, M. Repeatability and reproducibility of post-mortem central corneal thickness measurements using a portable optical coherence tomography system in humans: A prospective multicenter study. Sci. Rep. 2020, 10, 14508. [CrossRef] [PubMed] 
5. Coster, D.J.; Williams, K.A. The impact of corneal allograft rejection on the long-term outcome of corneal transplantation. Am. J. Ophthalmol. 2005, 140, 1112-1122. [CrossRef]

6. Naacke, H.G.; Borderie, V.M.; Bourcier, T.; Touzeau, O.; Moldovan, M.; Laroche, L. Outcome of Corneal transplantation rejection. Cornea 2001, 20, 350-353. [CrossRef] [PubMed]

7. Di Zazzo, A.; Gaudenzi, D.; Yin, J.; Coassin, M.; Fernandes, M.; Dana, R.; Bonini, S. Corneal angiogenic privilege and its failure. Exp. Eye Res. 2021, 204, 108457. [CrossRef] [PubMed]

8. Hori, J.; Yamaguchi, T.; Keino, H.; Hamrah, P.; Maruyama, K. Immune privilege in corneal transplantation. Prog. Retin. Eye Res. 2019, 72, 100758. [CrossRef]

9. Keino, H.; Horie, S.; Sugita, S. Immune Privilege and Eye-Derived T-Regulatory Cells. J. Immunol. Res. 2018, 2018. [CrossRef]

10. Niederkorn, J.Y. Corneal Transplantation and Immune Privilege. Int. Rev. Immunol. 2013, 32, 57-67. [CrossRef]

11. Subbannayya, Y.; Pinto, S.M.; Mohanty, V.; Dagamajalu, S.; Prasad, T.S.K.; Murthy, K.R. What Makes Cornea Immunologically Unique and Privileged? Mechanistic Clues from a High-Resolution Proteomic Landscape of the Human Cornea. Omics A J. Integr. Biol. 2020, 24, 129-139. [CrossRef] [PubMed]

12. Artifoni, M.; Rothschild, P.R.; Brezin, A.; Guillevin, L.; Puechal, X. Ocular inflammatory diseases associated with rheumatoid arthritis. Nat. Rev. Rheumatol. 2014, 10, 108-116. [CrossRef]

13. Yazici, A.T.; Kara, N.; Yuksel, K.; Altinkaynak, H.; Baz, O.; Bozkurt, E.; Demirok, A. The biomechanical properties of the cornea in patients with systemic lupus erythematosus. Eye 2011, 25, 1005-1009. [CrossRef] [PubMed]

14. Hamrah, P.; Huq, S.O.; Liu, Y.; Zhang, Q.; Dana, M.R. Corneal immunity is mediated by heterogeneous population of antigenpresenting cells. J. Leukoc. Biol. 2003, 74, 172-178. [CrossRef] [PubMed]

15. Randleman, J.B.; Stulting, R.D. Prevention and treatment of corneal graft rejection: Current practice patterns (2004). Cornea 2006, 25, 286-290. [CrossRef]

16. Borel, J.F.; Feurer, C.; Magnee, C.; Stahelin, H. Effects of the new anti-lymphocytic peptide cyclosporin A in animals. Immunology 1977, 32, 1017-1025.

17. Abudou, M.; Wu, T.; Evans, J.R.; Chen, X. Immunosuppressants for the prophylaxis of corneal graft rejection after penetrating keratoplasty. Cochrane Database Syst. Rev. 2015. [CrossRef]

18. Birnbaum, F.; Reis, A.; Bohringer, D.; Sokolowska, Y.; Mayer, K.; Voiculescu, A.; Oellerich, M.; Sundmacher, R.; Reinhard, T. An open prospective pilot study on the use of rapamycin after penetrating high-risk keratoplasty. Transplantation 2006, 81, 767-772. [CrossRef]

19. Stanbury, R.M.; Graham, E.M. Systemic corticosteroid therapy—Side effects and their management. Br. J. Ophthalmol. 1998, 82, 704-708. [CrossRef]

20. Tahvildari, M.; Emami-Naeini, P.; Omoto, M.; Mashaghi, A.; Chauhan, S.K.; Dana, R. Treatment of donor corneal tissue with immunomodulatory cytokines: A novel strategy to promote graft survival in high-risk corneal transplantation. Sci. Rep. 2017, 7, 971. [CrossRef]

21. Sandhu, H.S.; Hemmati, H.D.; Dana, R. Immune checkpoint inhibitors and corneal transplant rejection: A call for awareness. Immunotherapy 2020, 12, 947-949. [CrossRef]

22. Boisjoly, H.M.; Roy, R.; Dube, I.; Laughrea, P.A.; Michaud, R.; Douville, P.; Heebert, J. HLA-A,B and DR matching in corneal transplantation. Ophthalmology 1986, 93, 1290-1297. [CrossRef]

23. Shamseer, L.; Moher, D.; Clarke, M.; Ghersi, D.; Liberati, A.; Petticrew, M.; Shekelle, P.; Stewart, L.A.; Group, P.-P. Preferred reporting items for systematic review and meta-analysis protocols (PRISMA-P) 2015: Elaboration and explanation. BMJ 2015, 350, g7647. [CrossRef]

24. Stroup, D.F.; Berlin, J.A.; Morton, S.C.; Olkin, I.; Williamson, G.D.; Rennie, D.; Moher, D.; Becker, B.J.; Sipe, T.A.; Thacker, S.B. Meta-analysis of observational studies in epidemiology: A proposal for reporting. Meta-analysis Of Observational Studies in Epidemiology (MOOSE) group. JAMA 2000, 283, 2008-2012. [CrossRef] [PubMed]

25. Inomata, T.; Kitazawa, K.; Kuno, T.; Sung, J.; Nakamura, M.; Iwagami, M.; Takagi, H.; Midorikawa-Inomata, A.; Zhu, J.; Fujimoto, K.; et al. Clinical and Prodromal Ocular Symptoms in Coronavirus Disease: A Systematic Review and Meta-Analysis. Investig. Ophthalmol. Vis. Sci. 2020, 61, 29. [CrossRef]

26. Ross, J.; He, Y.G.; Pidherney, M.; Mellon, J.; Niederkorn, J.Y. The differential effects of donor versus host Langerhans cells in the rejection of MHC-matched corneal allografts. Transplantation 1991, 52, 857-861. [CrossRef] [PubMed]

27. Callanan, D.; Peeler, J.; Niederkorn, J.Y. Characteristics of rejection of orthotopic corneal allografts in the rat. Transplantation 1988, 45, 437-443. [CrossRef] [PubMed]

28. He, Y.G.; Niederkorn, J.Y. Depletion of donor-derived Langerhans cells promotes corneal allograft survival. Cornea 1996, 15, 82-89. [CrossRef] [PubMed]

29. Qian, Y.; Boisgerault, F.; Benichou, G.; Dana, M.R. Blockade of CD40-CD154 costimulatory pathway promotes survival of allogeneic corneal transplants. Investig. Ophthalmol. Vis. Sci. 2001, 42, 987-994.

30. Qian, Y.; Dana, M.R. Effect of locally administered anti-CD154 (CD40 ligand) monoclonal antibody on survival of allogeneic corneal transplants. Cornea 2002, 21, 592-597. [CrossRef]

31. Cursiefen, C.; Cao, J.; Chen, L.; Liu, Y.; Maruyama, K.; Jackson, D.; Kruse, F.E.; Wiegand, S.J.; Dana, M.R.; Streilein, J.W. Inhibition of hemangiogenesis and lymphangiogenesis after normal-risk corneal transplantation by neutralizing VEGF promotes graft survival. Investig. Ophthalmol. Vis. Sci. 2004, 45, 2666-2673. [CrossRef] 
32. Jin, Y.; Chauhan, S.K.; Saban, D.R.; Dana, R. Role of CCR7 in facilitating direct allosensitization and regulatory T-cell function in high-risk corneal transplantation. Investig. Ophthalmol. Vis. Sci. 2010, 51, 816-821. [CrossRef]

33. Cunnusamy, K.; Chen, P.W.; Niederkorn, J.Y. IL-17 promotes immune privilege of corneal allografts. J. Immunol. 2010, 185, 4651-4658. [CrossRef]

34. Cunnusamy, K.; Chen, P.W.; Niederkorn, J.Y. IL-17A-dependent CD4+CD25+ regulatory T cells promote immune privilege of corneal allografts. J. Immunol. 2011, 186, 6737-6745. [CrossRef]

35. Cho, Y.K.; Zhang, X.; Uehara, H.; Young, J.R.; Archer, B.; Ambati, B. Vascular Endothelial Growth Factor Receptor 1 morpholino increases graft survival in a murine penetrating keratoplasty model. Investig. Ophthalmol. Vis. Sci. 2012, 53, 8458-8471. [CrossRef]

36. Emami-Naeini, P.; Dohlman, T.H.; Omoto, M.; Hattori, T.; Chen, Y.; Lee, H.S.; Chauhan, S.K.; Dana, R. Soluble vascular endothelial growth factor receptor-3 suppresses allosensitization and promotes corneal allograft survival. Graefes Arch. Clin. Exp. Ophthalmol. 2014, 252, 1755-1762. [CrossRef]

37. Zhou, J.; Lu, X.H.; Dang, S.T.; Bai, L.; Zhang, Y.Q.; Xu, N. Subconjunctival interleukin-1 receptor antagonist inhibits graft rejection following high-risk penetrating keratoplasty in rats. Di Yi Jun Yi Da Xue Xue Bao 2004, 24, 539-541. [PubMed]

38. Jie, Y.; Zhang, W.H.; Pan, Z.Q.; Wu, Y.Y.; Wang, Y. Interleukin-1 receptor antagonist eye drops promoting high-risk corneal allografts survival in rats. Chin. Med. J. 2004, 117, 711-716. [PubMed]

39. Jie, Y.; Pan, Z.; Chen, Y.; Wei, Y.; Zhang, W.; Xu, L.; Wu, Y.; Peng, H. SEB combined with IL-1ra could prolong the survival of the rat allografts in high-risk corneal transplantation. Transpl. Proc. 2004, 36, 3267-3271. [CrossRef] [PubMed]

40. Chen, M.; Shi, W.Y.; Wang, F.H.; Xie, L.X. CTLA4-FasL protein for the prevention of immune rejection in mouse corneal transplantation. Zhonghua Yan Ke Za Zhi 2008, 44, 56-60. [PubMed]

41. He, Y.; Jie, Y.; Wang, B.; Zeng, H.; Zhang, Y.; Pan, Z. Adoptive transfer of donor corneal antigen-specific regulatory T cells can prolong mice corneal grafts survival. Cornea 2010, 29 (Suppl. 1), S25-S31. [CrossRef] [PubMed]

42. Yuan, J.; Liu, Y.; Huang, W.; Zhou, S.; Ling, S.; Chen, J. The experimental treatment of corneal graft rejection with the interleukin-1 receptor antagonist (IL-1ra) gene. PLoS ONE 2013, 8, e60714. [CrossRef]

43. Gao, X.W.; Fu, Y.; Li, W.J.; Du, A.J.; Li, X.; Zhao, X.D. Mechanism of immune tolerance induced by donor derived immature dendritic cells in rat high-risk corneal transplantation. Int. J. Ophthalmol. 2013, 6, 269-275. [CrossRef]

44. Yan, F.; Cai, L.; Hui, Y.; Chen, S.; Meng, H.; Huang, Z. Tolerogenic dendritic cells suppress murine corneal allograft rejection by modulating CD28/CTLA-4 expression on regulatory T cells. Cell Biol. Int. 2014, 38, 835-848. [CrossRef] [PubMed]

45. Li, B.; Tian, L.; Diao, Y.; Li, X.; Zhao, L.; Wang, X. Exogenous IL-10 induces corneal transplantation immune tolerance by a mechanism associated with the altered Th1/Th2 cytokine ratio and the increased expression of TGF-beta. Mol. Med. Rep. 2014, 9, 2245-2250. [CrossRef]

46. Xu, Q.; Tan, X.; Zhang, Y.; Jie, Y.; Pan, Z. Subconjunctival injection of in vitro transforming growth factor-beta-induced regulatory T cells prolongs allogeneic corneal graft survival in mice. Int. J. Clin. Exp. Med. 2015, 8, 20271-20278.

47. Hoffmann, F.; Zhang, E.P.; Pohl, T.; Kunzendorf, U.; Wachtlin, J.; Bulfone-Paus, S. Inhibition of corneal allograft reaction by CTLA4-Ig. Graefes Arch. Clin. Exp. Ophthalmol. 1997, 235, 535-540. [CrossRef]

48. Zhang, E.P.; Bulfone-Paus, S.; Hoffmann, F. Immunomodulation after keratoplasty by CTL4-Ig and anti-CD154 antibodies. Ophthalmologe 2002, 99, 183-187. [CrossRef]

49. Gong, N.; Pleyer, U.; Yang, J.; Vogt, K.; Hill, M.; Anegon, I.; Volk, H.D.; Ritter, T. Influence of local and systemic CTLA4Ig gene transfer on corneal allograft survival. J. Gene Med. 2006, 8, 459-467. [CrossRef] [PubMed]

50. Gong, N.; Pleyer, U.; Volk, H.D.; Ritter, T. Effects of local and systemic viral interleukin-10 gene transfer on corneal allograft survival. Gene 2007, 14, 484-490. [CrossRef] [PubMed]

51. Hos, D.; Bock, F.; Dietrich, T.; Onderka, J.; Kruse, F.E.; Thierauch, K.H.; Cursiefen, C. Inflammatory corneal (lymph)angiogenesis is blocked by VEGFR-tyrosine kinase inhibitor ZK 261991, resulting in improved graft survival after corneal transplantation. Investig. Ophthalmol. Vis. Sci. 2008, 49, 1836-1842. [CrossRef] [PubMed]

52. Bachmann, B.O.; Luetjen-Drecoll, E.; Bock, F.; Wiegand, S.J.; Hos, D.; Dana, R.; Kruse, F.E.; Cursiefen, C. Transient postoperative vascular endothelial growth factor (VEGF)-neutralisation improves graft survival in corneas with partly regressed inflammatory neovascularisation. Br. J. Ophthalmol. 2009, 93, 1075-1080. [CrossRef] [PubMed]

53. Hos, D.; Dorrie, J.; Schaft, N.; Bock, F.; Notara, M.; Kruse, F.E.; Krautwald, S.; Cursiefen, C.; Bachmann, B.O. Blockade of CCR7 leads to decreased dendritic cell migration to draining lymph nodes and promotes graft survival in low-risk corneal transplantation. Exp. Eye Res. 2016, 146, 1-6. [CrossRef]

54. Rocher, N.; Behar-Cohen, F.; Pournaras, J.A.; Naud, M.C.; Jeanny, J.C.; Jonet, L.; Bourges, J.L. Effects of rat anti-VEGF antibody in a rat model of corneal graft rejection by topical and subconjunctival routes. Mol. Vis. 2011, 17, 104-112. [PubMed]

55. Torres, P.F.; de Vos, A.F.; Martins, B.; Kijlstra, A. Interleukin 10 treatment does not prolong experimental corneal allograft survival. Ophthalmic Res. 1999, 31, 297-303. [CrossRef]

56. Krieger, N.R.; Fathman, C.G. The use of CD4 and CD8 knockout mice to study the role of T-cell subsets in allotransplant rejection. J. Heart Lung Transplant. Off. Publ. Int. Soc. Heart Transplant. 1997, 16, $263-267$.

57. Haskova, Z.; Usiu, N.; Pepose, J.S.; Ferguson, T.A.; Stuart, P.M. CD4+ T cells are critical for corneal, but not skin, allograft rejection. Transplantation 2000, 69, 483-487. [CrossRef] 
58. Appleby, S.L.; Jessup, C.F.; Mortimer, L.A.; Kirk, K.; Brereton, H.M.; Coster, D.J.; Tan, C.K.; Williams, K.A. Expression of an anti-CD4 single-chain antibody fragment from the donor cornea can prolong corneal allograft survival in inbred rats. Br. J. Ophthalmol. 2013, 97, 101-105. [CrossRef]

59. Ayliffe, W.; Alam, Y.; Bell, E.B.; McLeod, D.; Hutchinson, I.V. Prolongation of rat corneal graft survival by treatment with anti-CD4 monoclonal antibody. Br. J. Ophthalmol. 1992, 76, 602-606. [CrossRef]

60. Coupland, S.E.; Krause, L.; Karow, A.C.; Bartlett, R.R.; Lehmann, M.; Hoffmann, F. Delay in corneal allograft rejection due to anti-CD4 antibody given alone and in combination with cyclosporin A and leflunomide. Ger. J. Ophthalmol. 1995, 4, $294-301$.

61. He, Y.G.; Ross, J.; Niederkorn, J.Y. Promotion of murine orthotopic corneal allograft survival by systemic administration of anti-CD4 monoclonal antibody. Investig. Ophthalmol. Vis. Sci. 1991, 32, 2723-2728.

62. Li, S.; Lu, H.; Sella, R.; Zhang, W.; Dong, H.; Guo, C.; Afshari, N.A.; Pan, Z.; Jie, Y. The Effects of Anti-LAP Monoclonal Antibody Down-regulation of CD4+LAP+ T Cells on Allogeneic Corneal Transplantation in Mice. Sci. Rep. 2018, 8, 8021. [CrossRef] [PubMed]

63. Pleyer, U.; Milani, J.K.; Dukes, A.; Chou, J.; Lutz, S.; Rückert, D.; Thiel, H.J.; Mondino, B.J. Effect of topically applied anti-CD4 monoclonal antibodies on orthotopic corneal allografts in a rat model. Investig. Ophthalmol. Vis. Sci. 1995, 36, 52-61.

64. Hegde, S.; Niederkorn, J.Y. The role of cytotoxic T lymphocytes in corneal allograft rejection. Investig. Ophthalmol. Vis. Sci. 2000, $41,3341-3347$.

65. Niederkorn, J.Y.; Stevens, C.; Mellon, J.; Mayhew, E. Differential roles of CD8+ and CD8- T lymphocytes in corneal allograft rejection in 'high-risk' hosts. Am. J. Transpl. 2006, 6, 705-713. [CrossRef]

66. Maruyama, K.; Nakazawa, T.; Cursiefen, C.; Maruyama, Y.; Van Rooijen, N.; D'Amore, P.A.; Kinoshita, S. The maintenance of lymphatic vessels in the cornea is dependent on the presence of macrophages. Investig. Ophthalmol. Vis. Sci. 2012, 53, 3145-3153. [CrossRef]

67. Oh, J.Y.; Lee, H.J.; Ko, A.Y.; Ko, J.H.; Kim, M.K.; Wee, W.R. Analysis of macrophage phenotype in rejected corneal allografts. Investig. Ophthalmol. Vis. Sci. 2013, 54, 7779-7784. [CrossRef]

68. Slegers, T.P.; Broersma, L.; van Rooijen, N.; Hooymans, J.M.; van Rij, G.; van der Gaag, R. Macrophages play a role in the early phase of corneal allograft rejection in rats. Transplantation 2004, 77, 1641-1646. [CrossRef]

69. Slegers, T.P.; Torres, P.F.; Broersma, L.; van Rooijen, N.; van Rij, G.; van der Gaag, R. Effect of macrophage depletion on immune effector mechanisms during corneal allograft rejection in rats. Investig. Ophthalmol. Vis. Sci. 2000, 41, $2239-2247$.

70. Slegers, T.P.; van der Gaag, R.; van Rooijen, N.; van Rij, G.; Streilein, J.W. Effect of local macrophage depletion on cellular immunity and tolerance evoked by corneal allografts. Curr. Eye Res. 2003, 26, 73-79. [CrossRef]

71. Yamada, J.; Maruyama, K.; Sano, Y.; Kinoshita, S.; Murata, Y.; Hamuro, J. Promotion of corneal allograft survival by the induction of oxidative macrophages. Investig. Ophthalmol. Vis. Sci. 2004, 45, 448-454. [CrossRef] [PubMed]

72. Tahvildari, M.; Inomata, T.; Amouzegar, A.; Dana, R. Regulatory T cell modulation of cytokine and cellular networks in corneal graft rejection. Curr. Ophthalmol. Rep. 2018, 6, 266-274. [CrossRef] [PubMed]

73. Di Zazzo, A.; Tahvildari, M.; Subbarayal, B.; Yin, J.; Dohlman, T.H.; Inomata, T.; Mashaghi, A.; Chauhan, S.K.; Dana, R. Proangiogenic Function of T Cells in Corneal Transplantation. Transplantation 2017, 101, 778-785. [CrossRef] [PubMed]

74. Artis, D.; Spits, H. The biology of innate lymphoid cells. Nature 2015, 517, 293-301. [CrossRef] [PubMed]

75. Walsh, K.P.; Mills, K.H. Dendritic cells and other innate determinants of T helper cell polarisation. Trends Immunol. 2013, 34, 521-530. [CrossRef] [PubMed]

76. Zhu, J.; Inomata, T.; Fujimoto, K.; Uchida, K.; Fujio, K.; Nagino, K.; Miura, M.; Negishi, N.; Okumura, Y.; Akasaki, Y.; et al. Ex Vivo-Induced Bone Marrow-Derived Myeloid Suppressor Cells Prevent Corneal Allograft Rejection in Mice. Investig. Ophthalmol. Vis. Sci. 2021, 62, 3. [CrossRef] [PubMed]

77. Mellman, I.; Steinman, R.M. Dendritic cells: Specialized and regulated antigen processing machines. Cell 2001, 106, 255-258. [CrossRef]

78. Inomata, T.; Hua, J.; Nakao, T.; Shiang, T.; Chiang, H.; Amouzegar, A.; Dana, R. Corneal Tissue From Dry Eye Donors Leads to Enhanced Graft Rejection. Cornea 2018, 37, 95-101. [CrossRef] [PubMed]

79. Inomata, T.; Fujimoto, K.; Okumura, Y.; Zhu, J.; Fujio, K.; Shokirova, H.; Miura, M.; Okano, M.; Funaki, T.; Sung, J.; et al. Novel immunotherapeutic effects of topically administered ripasudil (K-115) on corneal allograft survival. Sci. Rep. 2020, 10, 19817. [CrossRef]

80. Hua, J.; Jin, Y.; Chen, Y.; Inomata, T.; Lee, H.; Chauhan, S.K.; Petasis, N.A.; Serhan, C.N.; Dana, R. The resolvin D1 analogue controls maturation of dendritic cells and suppresses alloimmunity in corneal transplantation. Investig. Ophthalmol. Vis. Sci. 2014, 55, 5944-5951. [CrossRef]

81. Sim, W.J.; Malinarich, F.; Fairhurst, A.M.; Connolly, J.E. Generation of Immature, Mature and Tolerogenic Dendritic Cells with Differing Metabolic Phenotypes. J. Vis. Exp. JoVE 2016, 10.3791/54128. [CrossRef] [PubMed]

82. Collin, M.; Milne, P. Langerhans cell origin and regulation. Curr. Opin. Hematol. 2016, 23, 28-35. [CrossRef]

83. Sano, Y.; Ksander, B.R.; Streilein, J.W. Fate of orthotopic corneal allografts in eyes that cannot support anterior chamber-associated immune deviation induction. Investig. Ophthalmol. Vis. Sci. 1995, 36, 2176-2185.

84. Williamson, J.S.; DiMarco, S.; Streilein, J.W. Immunobiology of Langerhans cells on the ocular surface. I. Langerhans cells within the central cornea interfere with induction of anterior chamber associated immune deviation. Investig. Ophthalmol. Vis. Sci. 1987, $28,1527-1532$. 
85. Peeler, J.; Niederkorn, J.; Matoba, A. Corneal allografts induce cytotoxic T cell but not delayed hypersensitivity responses in mice. Investig. Ophthalmol. Vis. Sci. 1985, 26, 1516-1523.

86. Yamaguchi, T.; Higa, K.; Yagi-Yaguchi, Y.; Ueda, K.; Noma, H.; Shibata, S.; Nagai, T.; Tomida, D.; Yasu-Mimura, R.; Ibrahim, O.; et al. Pathological processes in aqueous humor due to iris atrophy predispose to early corneal graft failure in humans and mice. Sci. Adv. 2020, 6, eaaz5195. [CrossRef]

87. Fust, A.; Csuka, D.; Imre, L.; Bausz, M.; Nagymihaly, A.; Fust, G.; Csorvasi, A.; Nemeth, J.; Varga, L. The role of complement activation in the pathogenesis of Fuchs' dystrophy. Mol. Immunol. 2014, 58, 177-181. [CrossRef]

88. Kerenyi, A.; Nagy, G.; Veres, A.; Varga, L.; Fust, A.; Nagymihany, A.; Czumbel, N.; Suveges, I.; Fust, G. C1r-C1s-C1inhibitor (C1rs-C1inh) complex measurements in tears of patients before and after penetrating keratoplasty. Curr. Eye Res. 2002, 24, 99-104. [CrossRef]

89. Zhang, X.; Shen, L.; Jin, Y.; Saban, D.R.; Chauhan, S.K.; Dana, R. Depletion of passenger leukocytes from corneal grafts: An effective means of promoting transplant survival? Investig. Ophthalmol. Vis. Sci. 2009, 50, 3137-3144. [CrossRef]

90. Islam, R.; Islam, M.M.; Nilsson, P.H.; Mohlin, C.; Hagen, K.T.; Paschalis, E.I.; Woods, R.L.; Bhowmick, S.C.; Dohlman, C.H.; Espevik, T.; et al. Combined blockade of complement C5 and TLR co-receptor CD14 synergistically inhibits pig-to-human corneal xenograft induced innate inflammatory responses. Acta Biomater. 2021, 127, 169-179. [CrossRef]

91. Hua, J.; Stevenson, W.; Dohlman, T.H.; Inomata, T.; Tahvildari, M.; Calcagno, N.; Pirmadjid, N.; Sadrai, Z.; Chauhan, S.K.; Dana, R. Graft Site Microenvironment Determines Dendritic Cell Trafficking Through the CCR7-CCL19/21 Axis. Investig. Ophthalmol. Vis. Sci. 2016, 57, 1457-1467. [CrossRef]

92. Abe, M.; Zahorchak, A.F.; Colvin, B.L.; Thomson, A.W. Migratory responses of murine hepatic myeloid, lymphoid-related, and plasmacytoid dendritic cells to CC chemokines. Transplantation 2004, 78, 762-765. [CrossRef]

93. Forster, R.; Schubel, A.; Breitfeld, D.; Kremmer, E.; Renner-Muller, I.; Wolf, E.; Lipp, M. CCR7 coordinates the primary immune response by establishing functional microenvironments in secondary lymphoid organs. Cell 1999, 99, 23-33. [CrossRef]

94. Bretscher, P.A. A two-step, two-signal model for the primary activation of precursor helper T cells. Proc. Natl. Acad. Sci. USA 1999, 96, 185-190. [CrossRef] [PubMed]

95. Iwata, M.; Soya, K.; Sawa, M.; Sakimoto, T.; Hwang, D.G. CD40 expression in normal human cornea and regulation of CD40 in cultured human corneal epithelial and stromal cells. Investig. Ophthalmol. Vis. Sci. 2002, 43, 348-357.

96. van Kooten, C.; Banchereau, J. Functions of CD40 on B cells, dendritic cells and other cells. Curr. Opin. Immunol. 1997, 9, 330-337. [CrossRef]

97. Graf, D.; Muller, S.; Korthauer, U.; van Kooten, C.; Weise, C.; Kroczek, R.A. A soluble form of TRAP (CD40 ligand) is rapidly released after T cell activation. Eur. J. Immunol. 1995, 25, 1749-1754. [CrossRef]

98. Quezada, S.A.; Jarvinen, L.Z.; Lind, E.F.; Noelle, R.J. CD40/CD154 interactions at the interface of tolerance and immunity. Annu. Rev. Immunol. 2004, 22, 307-328. [CrossRef]

99. Walker, L.S.; Sansom, D.M. The emerging role of CTLA4 as a cell-extrinsic regulator of T cell responses. Nat. Rev. Immunol. 2011, 11, 852-863. [CrossRef] [PubMed]

100. Nosov, M.; Wilk, M.; Morcos, M.; Cregg, M.; O’Flynn, L.; Treacy, O.; Ritter, T. Role of lentivirus-mediated overexpression of programmed death-ligand 1 on corneal allograft survival. Am. J. Transpl. 2012, 12, 1313-1322. [CrossRef]

101. Shen, L.; Jin, Y.; Freeman, G.J.; Sharpe, A.H.; Dana, M.R. The function of donor versus recipient programmed death-ligand 1 in corneal allograft survival. J. Immunol. 2007, 179, 3672-3679. [CrossRef] [PubMed]

102. Hori, J.; Wang, M.; Miyashita, M.; Tanemoto, K.; Takahashi, H.; Takemori, T.; Okumura, K.; Yagita, H.; Azuma, M. B7-H1-induced apoptosis as a mechanism of immune privilege of corneal allografts. J. Immunol. 2006, 177, 5928-5935. [CrossRef] [PubMed]

103. Sugita, S.; Usui, Y.; Horie, S.; Futagami, Y.; Yamada, Y.; Ma, J.; Kezuka, T.; Hamada, H.; Usui, T.; Mochizuki, M.; et al. Human corneal endothelial cells expressing programmed death-ligand 1 (PD-L1) suppress PD-1+ T helper 1 cells by a contact-dependent mechanism. Investig. Ophthalmol. Vis. Sci. 2009, 50, 263-272. [CrossRef] [PubMed]

104. Dutra, C.; Rocha Garcia, B.; Vieira, R.; Figueiredo, A.C.; Néron, Y. EP1.04-32 Successful Corneal Transplantation in a Patient Treated with Nivolumab for Metastatic Non-Small Cell Lung Cancer. J. Thorac. Oncol. 2019, 14, S981. [CrossRef]

105. Dinarello, C.A. Interleukin-1 in the pathogenesis and treatment of inflammatory diseases. Blood 2011, 117, 3720-3732. [CrossRef]

106. Rider, P.; Carmi, Y.; Guttman, O.; Braiman, A.; Cohen, I.; Voronov, E.; White, M.R.; Dinarello, C.A.; Apte, R.N. IL-1alpha and IL-1beta recruit different myeloid cells and promote different stages of sterile inflammation. J. Immunol. 2011, 187, 4835-4843. [CrossRef]

107. Dinarello, C.A.; van der Meer, J.W. Treating inflammation by blocking interleukin-1 in humans. Semin. Immunol. 2013, $25,469-484$. [CrossRef]

108. Solomon, A.; Rosenblatt, M.; Monroy, D.; Ji, Z.; Pflugfelder, S.C.; Tseng, S.C. Suppression of interleukin 1alpha and interleukin 1beta in human limbal epithelial cells cultured on the amniotic membrane stromal matrix. Br. J. Ophthalmol. 2001, 85, 444-449. [CrossRef]

109. Iwakura, Y.; Ishigame, H.; Saijo, S.; Nakae, S. Functional specialization of interleukin-17 family members. Immunity 2011, 34, 149-162. [CrossRef]

110. Subbarayal, B.; Chauhan, S.K.; Di Zazzo, A.; Dana, R. IL-17 Augments B Cell Activation in Ocular Surface Autoimmunity. J. Immunol. 2016, 197, 3464-3470. [CrossRef] 
111. Schofield, C.; Fischer, S.K.; Townsend, M.J.; Mosesova, S.; Peng, K.; Setiadi, A.F.; Song, A.; Baruch, A. Characterization of IL-17AA and IL-17FF in rheumatoid arthritis and multiple sclerosis. Bioanalysis 2016, 8, 2317-2327. [CrossRef] [PubMed]

112. Chae, W.J.; Gibson, T.F.; Zelterman, D.; Hao, L.; Henegariu, O.; Bothwell, A.L. Ablation of IL-17A abrogates progression of spontaneous intestinal tumorigenesis. Proc. Natl. Acad. Sci. USA 2010, 107, 5540-5544. [CrossRef] [PubMed]

113. Yin, X.T.; Zobell, S.; Jarosz, J.G.; Stuart, P.M. Anti-IL-17 therapy restricts and reverses late-term corneal allorejection. J. Immunol. 2015, 194, 4029-4038. [CrossRef]

114. Kwan, T.; Chadban, S.J.; Ma, J.; Bao, S.; Alexander, S.I.; Wu, H. IL-17 deficiency attenuates allograft injury and prolongs survival in a murine model of fully MHC-mismatched renal allograft transplantation. Am. J. Transpl. 2015, 15, 1555-1567. [CrossRef] [PubMed]

115. Inomata, T.; Mashaghi, A.; Di Zazzo, A.; Lee, S.M.; Chiang, H.; Dana, R. Kinetics of Angiogenic Responses in Corneal Transplantation. Cornea 2017, 36, 491-496. [CrossRef]

116. Shokirova, H.; Inomata, T.; Saitoh, T.; Zhu, J.; Fujio, K.; Okumura, Y.; Yanagawa, A.; Fujimoto, K.; Sung, J.; Eguchi, A.; et al. Topical administration of the kappa opioid receptor agonist nalfurafine suppresses corneal neovascularization and inflammation. Sci. Rep. 2021, 11, 8647. [CrossRef]

117. Ji, Y.W.; Lee, J.L.; Kang, H.G.; Gu, N.; Byun, H.; Yeo, A.; Noh, H.; Kim, S.; Choi, E.Y.; Song, J.S.; et al. Corneal lymphangiogenesis facilitates ocular surface inflammation and cell trafficking in dry eye disease. Ocul. Surf. 2018, 16, 306-313. [CrossRef]

118. Nebbioso, M.; Iannaccone, A.; Duse, M.; Aventaggiato, M.; Bruscolini, A.; Zicari, A.M. Vascular Endothelial Growth Factor (VEGF) Serological and Lacrimal Signaling in Patients Affected by Vernal Keratoconjunctivitis (VKC). J. Ophthalmol. 2018, 2018, 3850172. [CrossRef]

119. Di Zazzo, A.; Kheirkhah, A.; Abud, T.B.; Goyal, S.; Dana, R. Management of high-risk corneal transplantation. Surv. Ophthalmol. 2017, 62, 816-827. [CrossRef]

120. Zhong, W.; Montana, M.; Santosa, S.M.; Isjwara, I.D.; Huang, Y.H.; Han, K.Y.; O’Neil, C.; Wang, A.; Cortina, M.S.; de la Cruz, J.; et al. Angiogenesis and lymphangiogenesis in corneal transplantation-A review. Surv. Ophthalmol. 2018, 63, 453-479. [CrossRef]

121. Inomata, T.; Hua, J.; Di Zazzo, A.; Dana, R. Impaired Function of Peripherally Induced Regulatory T Cells in Hosts at High Risk of Graft Rejection. Sci. Rep. 2016, 6, 39924. [CrossRef]

122. You, I.C.; Kang, I.S.; Lee, S.H.; Yoon, K.C. Therapeutic effect of subconjunctival injection of bevacizumab in the treatment of corneal neovascularization. Acta Ophthalmol. 2009, 87, 653-658. [CrossRef] [PubMed]

123. Doctor, P.P.; Bhat, P.V.; Foster, C.S. Subconjunctival bevacizumab for corneal neovascularization. Cornea 2008, $27,992-995$. [CrossRef]

124. Buznyk, O.; Azharuddin, M.; Islam, M.M.; Fagerholm, P.; Pasyechnikova, N.; Patra, H.K. Collagen-based scaffolds with infused anti-VEGF release system as potential cornea substitute for high-risk keratoplasty: A preliminary in vitro evaluation. Heliyon 2020, 6, e05105. [CrossRef]

125. Lam, A.J.; Hoeppli, R.E.; Levings, M.K. Harnessing Advances in T Regulatory Cell Biology for Cellular Therapy in Transplantation. Transplantation 2017, 101, 2277-2287. [CrossRef] [PubMed]

126. Swart, J.F.; Delemarre, E.M.; van Wijk, F.; Boelens, J.J.; Kuball, J.; van Laar, J.M.; Wulffraat, N.M. Haematopoietic stem cell transplantation for autoimmune diseases. Nat. Rev. Rheumatol. 2017, 13, 244-256. [CrossRef]

127. Tahvildari, M.; Omoto, M.; Chen, Y.; Emami-Naeini, P.; Inomata, T.; Dohlman, T.H.; Kaye, A.E.; Chauhan, S.K.; Dana, R. In Vivo Expansion of Regulatory T Cells by Low-Dose Interleukin-2 Treatment Increases Allograft Survival in Corneal Transplantation. Transplantation 2016, 100, 525-532. [CrossRef] [PubMed]

128. Inomata, T. A New Immunotherapy Using Regulatory T-Cells for High-Risk Corneal Transplantation. Juntendo Med. J. 2017, 63, 2-7. [CrossRef]

129. Maier, P.; Heizmann, U.; Bohringer, D.; Kern, Y.; Reinhard, T. Predicting the risk for corneal graft rejection by aqueous humor analysis. Mol. Vis. 2011, 17, 1016-1023.

130. Hayashi, T.; Takahashi, H.; Inoda, S.; Shimizu, T.; Kobayashi, A.; Kawashima, H.; Yamaguchi, T.; Yamagami, S. Aqueous humour cytokine profiles after Descemet's membrane endothelial keratoplasty. Sci. Rep. 2021, 11, 17064. [CrossRef]

131. Funding, M.; Vorum, H.; Nexo, E.; Moestrup, S.K.; Ehlers, N.; Moller, H.J. Soluble CD163 and interleukin-6 are increased in aqueous humour from patients with endothelial rejection of corneal grafts. Acta Ophthalmol. Scand. 2005, 83, 234-239. [CrossRef] [PubMed]

132. Funding, M.; Hansen, T.K.; Gjedsted, J.; Ehlers, N. Simultaneous quantification of 17 immune mediators in aqueous humour from patients with corneal rejection. Acta Ophthalmol. Scand. 2006, 84, 759-765. [CrossRef] [PubMed]

133. Maier, P.; Heizmann, U.; Bohringer, D.; Kern, Y.; Reinhard, T. Distinct cytokine pattern in aqueous humor during immune reactions following penetrating keratoplasty. Mol. Vis. 2010, 16, 53-60. [PubMed]

134. Lohan, P.; Murphy, N.; Treacy, O.; Lynch, K.; Morcos, M.; Chen, B.; Ryan, A.E.; Griffin, M.D.; Ritter, T. Third-Party Allogeneic Mesenchymal Stromal Cells Prevent Rejection in a Pre-sensitized High-Risk Model of Corneal Transplantation. Front. Immunol. 2018, 9, 2666. [CrossRef]

135. Dekaris, I.; Gabric, N.; Draca, N.; Pauk-Gulic, M.; Milicic, N. Three-year corneal graft survival rate in high-risk cases treated with subconjunctival and topical bevacizumab. Graefes Arch. Clin. Exp. Ophthalmol. 2015, 253, 287-294. [CrossRef]

136. Vassileva, P.I.; Hergeldzhieva, T.G. Avastin use in high risk corneal transplantation. Graefes Arch. Clin. Exp. Ophthalmol. 2009, 247, 1701-1706. [CrossRef] 
137. Trufanov, S.V.; Malozhen, S.A.; Krakhmaleva, D.A.; Surnina, Z.V.; Pivin, E.A.; Kasparova, E.A. Antiangiogenic therapy in high-risk keratoplasty. Vestn Oftalmol. 2020, 136, 11-18. [CrossRef]

138. Di Zazzo, A.; Micera, A.; Coassin, M.; Varacalli, G.; Foulsham, W.; De Piano, M.; Bonini, S. InflammAging at Ocular Surface: Clinical and Biomolecular Analyses in Healthy Volunteers. Investig. Ophthalmol. Vis. Sci. 2019, 60, 1769-1775. [CrossRef]

139. Hua, J.; Inomata, T.; Chen, Y.; Foulsham, W.; Stevenson, W.; Shiang, T.; Bluestone, J.A.; Dana, R. Pathological conversion of regulatory $\mathrm{T}$ cells is associated with loss of allotolerance. Sci. Rep. 2018, 8, 7059. [CrossRef]

140. Di Zazzo, A.; Lee, S.-M.; Sung, J.; Niutta, M.; Coassin, M.; Mashaghi, A.; Inomata, T. Variable Responses to Corneal Grafts: Insights from Immunology and Systems Biology. J. Clin. Med. 2020, 9, 586. [CrossRef] 